Elsevier required licence: ( 2019

This manuscript version is made available under the CC-BY-NC-ND 4.0 license http://creativecommons.org/licenses/by-nc-nd/4.0/

The definitive publisher version is available online at https://doi.org/10.1016/j.jclepro.2019.05.051 


\title{
Extending the Supply Chain to Address Sustainability
}

\author{
Firouzeh Taghikhah $^{a^{*}}$, Alexey Voinov ${ }^{a}$, Nagesh Shukla ${ }^{a}$ \\ a Center on Persuasive Systems for Wise Adaptive Living, \\ School of Information, Systems and Modelling \\ Faculty of Engineering and Information Technology, University of Technology Sydney, \\ NSW 2007, Australia \\ Email: \{Firouzeh.Taghikhah, Alexey.Voinov, Nagesh.Shukla\} @uts.edu.au \\ * Corresponding Author
}

\begin{abstract}
In today's growing economy, overconsumption and overproduction have accelerated environmental deterioration worldwide. Consumers, through unsustainable consumption patterns, and producers, through production based on traditional resource depleting practices, have contributed significantly to the socio-environmental problems. Consumers and producers are linked by supply chains, and as sustainability became seen as a way to reverse socio-environmental degradation, it has also started to be introduced in research on supply chains. We look at the evolution of research on sustainable supply chains and show that it is still largely focused on the processes and networks that take place between the producer and the consumer, hardly taking into account consumer behavior and its influence on the performance of the producer and the supply chain itself. We conclude that we cannot be talking about sustainability, without extending the supply chains to account for consumers' behavior and their influence on the overall system performance. A conceptual framework is proposed to explain how supply chains can become sustainable and improve their economic and socio-environmental performance by motivating consumer behavior toward green consumption patterns, which, in turn, motivate producers and suppliers to change their operations.
\end{abstract}

Keywords: Circular supply chain, Sustainable production-consumption, Environmental behavior, Green Consumer

\section{Highlights}

- To address sustainability, traditional supply chains need to be extended to include consumers

- Responsible production is not enough for sustainability - we need responsible consumption

- Changing consumer behavior plays a key role in transitioning to sustainability 


\section{Introduction}

Traditionally, profit enhancement and cost leadership were the primary focus of supply chain (SC) management (SCM). However, more recently, the increasing rate of environmental degradation and resource depletion caused by economic growth have shifted focus to socio-environmental issues, which in the context of SC research led to more concern about sustainability, and the concept of a Sustainable Supply Chain (SSC) has emerged. At first, SSCs were to consider economic, environmental and social concerns in all activities along the supply chain, from the point of origin to the point of consumption. Later, this was supplemented by ideas of reuse and recycling borrowed from the circular economy concepts. In Circular Supply Chains (CSC) sustainability was to be a concern over the entire value chain, from cradle to grave. In this transitioning to SSC and then to CSC, the issues of logistics network planning based on green initiatives, green production and inventory management, waste management and eco-product design have been brought into consideration.

However, the role of consumption, and consumer behavior has been largely ignored in the literature on SC. Sustainable consumption or green consumer behavior refers to customers' choice not to purchase and use environmentally harmful products, and instead consume products that benefit the environment (Elkington \& Hailes, 1988; Steg \& Vlek, 2009). Sustainable consumption patterns can considerably decrease the social and environmental impacts (Steg \& Vlek, 2009). According to the Intergovernmental Panel on Climate Change (IPCC) report, global warming caused by energy-related emissions (over the 21st century) can be contained to less than $2^{\circ} \mathrm{C}$ over pre-industrial levels by just switching to responsible energy consumption and changing dietary preferences (IPCC, 2015). World Business Council for Sustainable Development stressed that changing consumer behavior towards more sustainable purchases can be accomplished throughout the supply chain (Mead, 2018). Supply chains are responsible for encouraging pro-environmental behavior of customers and their willingness to pay for the green premiums. Since there are usually additional costs of sustainable practices, green products tend to be more expensive than conventional products (Nidumolu, Prahalad, \& Rangaswami, 2009). Thus, if consumers have no awareness of the advantages of green products, they may be not willing to pay for them, and there will be no incentives for supply chains to adopt green practices.

Almost five years ago, Pagell and Shevchenko (2014) have noticed that sustainability and SC research are difficult to marry and expressed huge concerns about the future of research on sustainable SC. They have suggested that "Future SCM research will have to treat a supply chain's social and environmental performance as equally or more valid than economic performance. Clearly, this was not and hardly is happening. As a solution Pagell and Shevchenko (2014) proposed changes in norms, measurement, methods, and research questions. Some of this resonates with the current proposals of developing SC in ways that would resemble how natural systems work (Gruner \& Power, 2017). We think that since sustainability is largely a social concept (since after all, the natural and especially the economic function of systems is important only for the sake of social benefits (Voinov, 2017), it makes little sense to analyze SSC unless they include the social systems that they interact with.

In this paper, we argue that - to be successful in operationalizing sustainability in the context of SC, consumer behavior has to be considered as part of the SC analysis. We propose a conceptual framework, the "extended sustainable supply chain" (ESSC), in which 
the relationship between buying behavior of consumers and SSC operation is considered. We argue that by motivating sustainable consumer behavior, we can, in turn, drive the decisions along the whole SC, also influencing the production process. The key message of ESSC is that producing and consuming can both become more responsible and sustainable if behavioral as well as operational aspects are taken into account.

From the theoretical perspective, we highlight the holistic view of sustainability goals in SSC and emphasize the role of consumption patterns in SC operation. From the managerial perspective, this study explains how the financial risk of moving towards SSC can be mitigated through increasing the market share of green products and investing in consumer awareness and acceptance campaigns. We offer several examples of SC where management focused on modifying consumer preferences toward more sustainable products and SC operations. This in turn increased the overall profitability of the SC. In this paper, we start with a broad review of the evolution of sustainable supply chain literature. The proposed conceptual framework of ESSC is presented in section 3. The implications and conclusions are discussed in section 4.

\section{Evolving View on Sustainability in Supply Chains}

There are quite a few recent literature reviews available on sustainable and green supply chains. For e.g. Govindan, Soleimani, and Kannan (2015), Ansari and Kant (2017), BarbosaPóvoa, da Silva, and Carvalho (2017), Bastas and Liyanage (2018) and Koberg and Longoni (2018). In this paper, we focus on the evolution of the SSC concept in literature to show how it was gradually embracing additional ideas and mechanisms relevant to sustainability, while stopping short of including the consumer behavior into the picture. Some of the most important papers in this area include publications by White and Lee (2009), who discussed a framework for integration of social sustainability in SSC analytical approaches, Jaehn (2016), who gave an overview of sustainable operations, Stindt (2017), who described a general framework for decision-making in SSC, and Gaur, Subramoniam, Govindan, and Huisingh (2016), who presented an overview of behavioral and operational aspects of waste collection and reverse logistics. Logistics and transportation, network design, production operation and product design are the most discussed topics in the SSC context. While there are hundreds of papers published in this area, here we mention only the most relevant ones as illustrations for each topic, for each category of SC analyses in the typology that we have identified. They are critically compared and contrasted so that the gap of what still needs to be known and researched can be identified.

Scientific databases such as Scopus and ScienceDirect were used to search for relevant papers containing keywords such as "sustainable" or "green" together with "supply chain" and "closed-loop supply chain" within their title, abstract, or keywords.

\subsection{Traditional Supply Chain}

With the emergence of globalization, most small and large organizations have realized the need for intercontinental integration to compete in the global market. The goals of gaining competitive advantage and reducing business costs could be reached only through extensive cooperation and expansion beyond national boundaries and into other continents. Supply chain research has emerged as a modern commerce solution to leverage this shift to 
the networked economy (Tseng \& Hung, 2014). The supply chain term, initially defined by Oliver and Webber (1982), refers to the systematic collaboration between people, processes, and information of alike organizations to create tangible (i.e., product) or intangible (i.e., service) values and deliver them to the customers. In this regard, supply chain management evaluates and aligns end-to-end business processes with the market demand to create competitive advantage over the rivals, while it does not consider how the demand is generated.

In the digital age, more complexity could be afforded when analyzing supply chains which changed its management perspective to accommodate flexibility, agility, and adaptability. This broader perspective implies the need for extending the supply chain objective from overall supply chain cost reduction to operational efficiency improvement. Aligned with this change, the primary focus of research papers on supply chains shifted from pure economic goals to operational goals (Goetschalcks \& Fleischmann, 2008). Reducing the total costs of supply chain operation, increasing the total income, and eliminating the asset's exposure to risk are some examples of financial goals supply chains sought to attain in the long-term (Goetschalcks \& Fleischmann, 2008; Stadtler, 2008). To survive in increasingly competitive business environment, competitive strategy formulation could assist supply chains in gaining market leadership and maximizing the return on investment (Giunipero, Hooker, \& Denslow, 2012). Time management, an important element in operation efficiency, and a source of competitive advantage, was the focus of supply chain studies for a long time. Following the time-based strategy, new technologies, based on highly-automated systems, and highspeed communication routes were developed to shorten delivery time of orders. Enhancing customer services, upgrading the quality of products, product customization, and building resilience were the other examined strategies for gaining competitive results (Christopher, 2016).

To achieve the determined competitive strategies, the core business functions of supply chains including transportation and logistics, manufacturing and service, and procurement were to be re-evaluated and re-designed (Mentzer et al., 2001). Many avenues of research on supplier selection and management, production planning and process optimization, logistics and distribution, transportation selection, workforce scheduling, resilience and risk assessment, finance and accounting have been developed for supply chain management (Kouvelis, Chambers, \& Wang, 2006). Figure 1 represents the major players involved in traditional supply chains. Analyses of how exactly the materials were produced and supplied and how the products were used by the customers was beyond the boundaries of supply chain research.

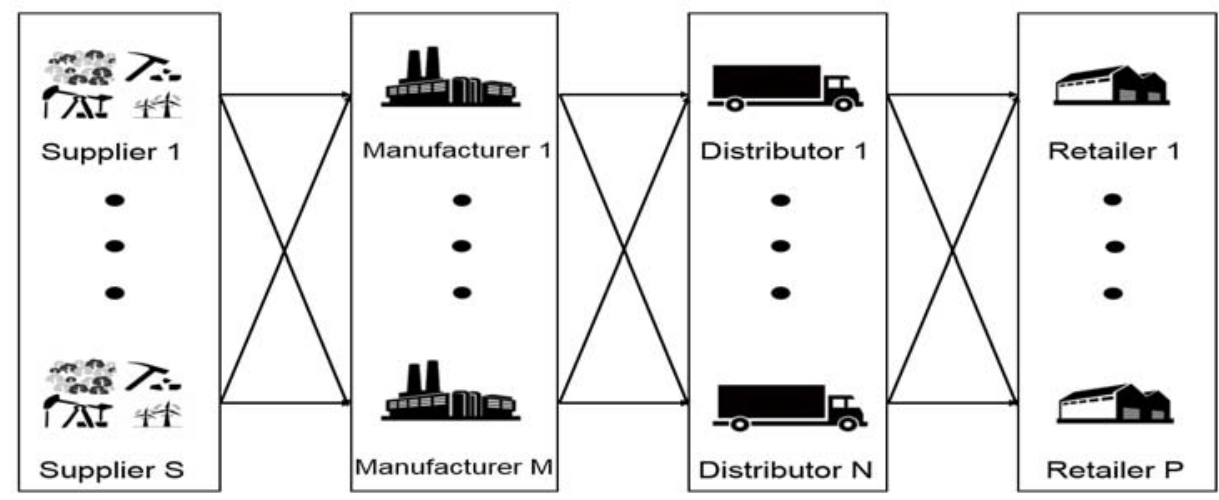

Figure 1. Major players of a traditional supply chain 


\subsection{Sustainable Supply Chain}

Throughout the human history, deforestation, loss of soil fertility, and water shortage have been ever-growing ecological issues resulting from farming, mining and other human practices (Du Pisani, 2006). Maintaining the "everlasting youth" of the earth or what we today call "sustainability" was a matter of discussion since the 5th century. Sustainability as a term had first appeared in the German forestry industry in 1713 when there was a shortage of wood supply in Europe. This promoted forest conservation, preservation and tree planting programs (Du Pisani, 2006). Concerns about population growth, uncontrolled industrial and economic growth, and non-renewable resource depletion increased following the first oil crisis of 1973 (Du Pisani, 2006). Evolving over the years, sustainability has been discussed in various contexts and was presented in a number of ways to draw the attention to the environmental issues and the necessity to take serious actions. Most studies in Sustainable Supply Chain (SSC) literature were developed based on Brundtland commission definition for sustainability as meeting the needs of today without compromising the ability to meet the needs of the future generations (WCED 1987). While there are serious concerns about the meaning of this definition and vagueness about what present and future needs are, and what should be sustained (Voinov, 2017), the Brundtland report was pivotal to introduce the ideas of sustainable development to the political process.

Today, the challenge of sustainability is among the top 10 unresolved global concerns and still draws much attention (Global Agenda Council on Climate Change 2018). To address this concern, legislatures and governments, issued environmental laws describing a set of preventive-protective policies, regulations, and procedures (Ageron, Gunasekaran, \& Spalanzani, 2012). The environmental laws accompanied by the societal norms and values, the stakeholders' awareness, and organizational culture, directly and indirectly, affected the management strategies of many businesses. Environmental impacts related to the supply chains in most sectors are considered to be increasingly important for sustainable development. Under external and internal pressures, businesses decide whether they want to change taking into account environmental concerns, and if so what changes should be made in their supply chains. SSC is the incorporation of socio-environmental sustainability goals into the systematic arrangement of key inter-business functions along a chain. It was seen as a potential solution to improve the sustainability performance in the long-term (Carter \& Rogers, 2008).

A number of terms such as green supply chain (Srivastava, 2007), low-carbon supply chain (Shaw, Shankar, Yadav, \& Thakur, 2012), social supply chain (Hutchins \& Sutherland, 2008) and ethical supply chain (Seuring \& Müller, 2008) can be found in the SSC literature. Green supply chain referred to the idea of synchronizing green thinking with sourcing raw materials, producing a product and delivering it to the final customer to gain competitive advantage in terms of environmental sustainability (Srivastava, 2007). Social supply chain, on the other hand, was the term used for supply chains that made a trade-off between their economic goals and social responsibilities to improve their shared values with stakeholders (Porter \& Kramer, 2011). SSC was associated with the application of the triple bottom line indicators, a well-established sustainability framework, to supply chains (Gimenez, Sierra, \& Rodon, 2012). SSC encompassed three distinct economic, environmental and social dimensions for sustainability. The competitive advantage of SSC can be achieved in the intersection of these dimensions (Elkington, 2013). However, the challenge of integrating different sustainability performance was yet to be addressed (Ansari \& Kant, 2017). 
For transitioning to sustainability, managers revisited their current operations and identified opportunities for mitigating the relevant impacts in specific areas within supply chains (Brandenburg \& Rebs, 2015). Logistics arose as the primary environmentally and socially sensitive operation in supply chains. Many papers focused on different aspects of logistics including transportation, distribution, and network design to decrease the stress on ecology and society for long-term viability (Brandenburg, Govindan, Sarkis, \& Seuring, 2014; Fahimnia, Sarkis, \& Davarzani, 2015). More specifically, the environmental values (e.g., the reduction of carbon emissions, energy consumption) and social values (e.g., welfare of society, labor condition, and ethical practices) were incorporated into the evaluation, selection, and design of logistic networks.

Consider, for example, the transportation mode problem in logistics as it significantly contributes to the issue of climate change. According to World Bank (2014), 20\% of the World carbon dioxide (CO2) emissions were generated from transportation and logistics. Almost all primary modes of transport have harmful environmental impacts. Sustainable logistics studies are continuously looking for green modes of transportation to decrease their carbon and energy footprints. One way is to facilitate the use of environmentally-friendly transport such as trains and ships/barges to decrease emissions (Jaehn, 2016). These transportation modes have been less popular in supply chains. The low utilization rate of low-impact transport was mainly related to the issue of poor accessibility. To address this issue, intermodal transportation studies have been conducted in order to combine the most eco-friendly modes and give easy access to customers (Kirschstein \& Meisel, 2015). Shared/ joint transport was another way for decreasing the environmental impacts by intensifying use of vehicles or by ride-sharing. In joint transportation, a supply chain may decide whether to join another supply chain transport, so that the logistic costs can be redistributed among the partners (depending on the cost-sharing agreement) and the total emissions would be reduced (Boyacı, Zografos, \& Geroliminis, 2015).

Vehicle routing is another way to reduce environmental impacts. The routes for a fleet of vehicles could be optimized with regard to costs and emissions. The emission reduction goal for route selection was pursued through minimizing the energy/fuel consumption (Bektaş, Demir, \& Laporte, 2016). The rate of fuel consumption, in turn, was determined by various factors including the travel distance and speed (Demir, Bektaş, \& Laporte, 2014; Osmani \& Zhang, 2017), travel time, and the number and type of vehicles used (Lin, Choy, Ho, Chung, \& Lam, 2014). The integration of emissions reduction goals in vehicle routing can backfire, when rerouting results in more traffic, higher fuel consumption and emissions (Jaehn, 2016). Furthermore, the harmful impacts of vehicle routing may cause other environmental impacts such as noise pollution or increase in impervious surfaces created by new roads. The electric fleet routing problem as an alternative option to deal with environmental pollution has attracted much attention in SSC logistics (Hiermann, Puchinger, Ropke, \& Hartl, 2016). The challenges of electric vehicle/fleet such as the long recharging times (Chung \& Kwon, 2015; Eberle \& Von Helmolt, 2010), smaller capacities (Richardson, 2013), and limited availability of recharging stations (Desaulniers, Errico, Irnich, \& Schneider, 2016) were studied by a number of researchers. Although electric fleet can decrease pollution, the environmental impact of their batteries and generation of electricity have raised many concerns. The social aspects of transportation were rarely incorporated into SSC studies. Providing goods and services to people in remote areas, giving quicker accessibility to central facilities (e.g., schools, hospitals), noise pollution and accidents caused by traffic were rarely cited by 
scholars. Overall, it should be noted that in all these cases the 'sustainability' or 'greening' of the SC was usually well connected to overall economic efficiency of the operations.

Sustainability issues became also important in logistics network design where social sustainability was given considerable importance. This branch of logistics was about determining the optimal location for one or more facilities to meet various, perhaps conflicting, demands. To find a suitable location, a set of potential sites for facilities were preselected and ranked with regards to economic, environmental and social considerations. Then, the spatial locations of all the other available facilities involved in the supply chain were identified. Finally, the desired number and location of new facilities were determined such that adverse impacts were minimized and the customer demands were satisfied. The optimal production allocation to different facilities and the optimal distribution of commodities from facilities to customers with regard sustainability objectives (e.g., cost reduction, ecological benefit, and public accessibility) were considered in several papers (Eskandarpour, Dejax, Miemczyk, \& Péton, 2015). Most SSC network design studies aimed at minimizing the ecological impacts (e.g., reducing emissions) through minimizing transportation (Bouzembrak, Allaoui, Goncalves, \& Bouchriha, 2013; Zhang, Wiegmans, \& Tavasszy, 2013); nevertheless, there were studies considering the environmental impacts of facilities as well, by examining their energy efficiencies (Devika, Jafarian, \& Nourbakhsh, 2014; Govindan, Jafarian, Khodaverdi, \& Devika, 2014).

We can argue that these types of SSC had a strong flavor of 'green-washing', since optimizing transport, routing and networks was actually also a way to improve the conventional profitability of the operations. The fact that some greenhouse gases could be also saved came as a nice complementary factor, which could be further used for publicity purposes.

Regarding the social aspects, the employment indicator was often considered in SSC studies. Employment can be measured, for instance, as the total number of jobs created (Osmani \& Zhang, 2017; Santibañez-Aguilar, González-Campos, Ponce-Ortega, SernaGonzález, \& El-Halwagi, 2014), the total number of variable and fixed jobs created (Mota, Gomes, Carvalho, \& Barbosa-Povoa, 2015; You, Tao, Graziano, \& Snyder, 2012), total number of created jobs in less developed regions (Varsei \& Polyakovskiy, 2017; Zhalechian, Tavakkoli-Moghaddam, Zahiri, \& Mohammadi, 2016), or the number of new employees in the local economy (Miret, Chazara, Montastruc, Negny, \& Domenech, 2016). Safety, another frequently used indicator is quantified by accounting for the injury rate (Bouchery, Ghaffari, Jemai, \& Dallery, 2012), the number of working hours in every facility, and the health and safety index of work environment (Santibañez-Aguilar, Ponce-Ortega, González-Campos, Serna-González, \& El-Halwagi, 2013). In some cases, indicators were used to assess two or more social factors at the same time. For example, Dehghanian and Mansour (2009) used a multi-criteria decision making approach to weight and integrate employment, damage to workers, product risk, and local development criteria into a single social indicator. Similarly, Devika et al. (2014) aggregated indicators of employment and safety in one to assess the social impacts of designed network. Social objectives such as accessibility to goods and services (e.g., food), equality in access to public utilities (e.g., healthcare, schools) (Beheshtifar \& Alimoahmmadi, 2015) and the risk of exposure to chemical and toxic wastes (Pishvaee, Razmi, \& Torabi, 2012) (for product and facility) were rarely mentioned in the SSC literature. A summary of topics discussed in SSC is presented in Figure 2. 


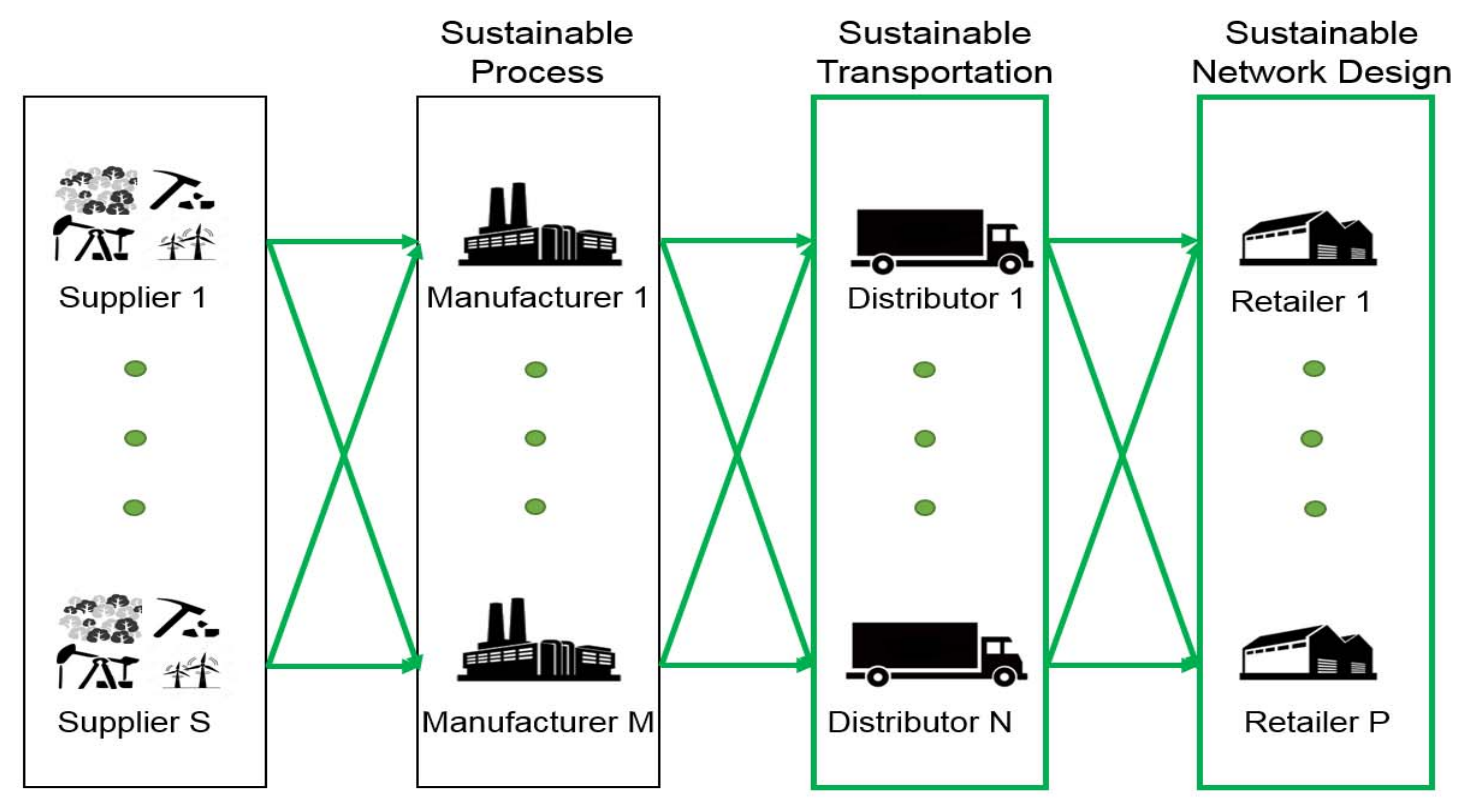

Figure 2. Scope of sustainable supply chain

\subsection{Circular Economy and Sustainable Supply Chain}

As we go deeper in analyzing sustainability performance, we realize that obtaining sustainable outcomes should be considered through extending producer responsibility (Mena, Humphries, \& Choi, 2013; Vachon \& Klassen, 2006). It was suggested that the responsibilities of producers for dealing with sustainability issues should not end once the products are sold to customers. There should be some accountability for impacts of products during consumption and in post-consumption phase and therefore waste and 'end-of-life' management programs should be adopted. As such, the linear paradigm of supply chain has changed to a circular one.

Circular economy concept is being considered as a potential solution to address sustainable development challenges, improving the economic-environmental productivity ratio of business systems by decreasing the inputs rather than increasing the outputs (Geissdoerfer, Savaget, Bocken, \& Hultink, 2017). The integration of the circular economy concept into the supply chain became known as "circular supply chain" (CSC) or "closedloop supply chain." Both terms appear in literature and are used interchangeably in this paper. Input materials into the CSC are reduced since some of the generated wastes are retrieved to be used again as resources. Thus, the energy and resource dependencies could be reduced without influencing the development and growth of the operations (Geissdoerfer, Morioka, de Carvalho, \& Evans, 2018). In fact, CSCs operationalize circular economy concept through slowing, narrowing, intensifying and closing resource loops (Bocken, de Pauw, Bakker, \& van der Grinten, 2016). As the management of CSC does not terminate at the point of sale, reverse logistics and waste management should be examined in coordination with the functional areas of forward logistics.

In reverse logistics, the closing loop of supply chains provides a feedback flow from the point of consumption to the point of origin to return items after they served their original purpose. In particular, non-functional products and waste are collected from their typical final 
destination for the purpose of recapturing values through reusing, remanufacturing, and recycling (Gaur et al., 2016). Though recovering or recycling the end of life products turn out to be eco-friendly activities, the energy intensity and pollution generation of backward transportation and treatment facilities should be considered. The transportation planning and network design problems in reverse logistics were very much the same as the forward logistics. However, the risks and uncertainties involved in quantity, frequency and quality of collected products make these problems more complex (Govindan et al., 2015).

The collected end-of-life items can be sorted for recovery purposes depending on the type of materials used. Product recovery refers to recapturing value from damaged products, seasonal inventory, recalled items, and end-of-life products. The condition of returns determines whether they are suitable for repair/reuse, refurbishing, or remanufacturing. Repair-reuse is the most forward-thinking approach preventing extra costs of treatment. Due to their waste preventing nature, this approach should be given priority in the product recovery hierarchy. In refurbishing and remanufacturing, the defects of the returned product are repaired or replaced with new components resulting in a relatively lower quality product with a lower price. The challenges of product recovery problems are mainly concerned with predicting the quantity (Clottey, Benton Jr, \& Srivastava, 2012), quality and deciding on optimum prices and production rates for remanufactured/refurbished products (Bulmuş, Zhu, \& Teunter, 2014; Xiong, Zhou, Li, Chan, \& Xiong, 2013).

As a part of the reverse logistics process, waste management is also committed to sustainability objectives. Waste management problem raises the questions of which disposing option including recycling, incineration or landfill should be selected for each type of waste and where to locate the corresponding facilities. Recycling at end-of-life meets the raw material requirements of new products and thus adds sustainability value to the chain. Incineration and landfill, while perhaps economically more profitable, are non-value adding approaches that can be utilized as the last solution. In waste management problem, issues such as the allocation of waste flow (Battarra, Erdoğan, \& Vigo, 2014), the routing of collection vehicles (Benjamin \& Beasley, 2010), and the scheduling of collection times (Faccio, Persona, \& Zanin, 2011) are addressed in regards to socio-ecological impacts. A special topic in this context focuses on locating disposal plants for hazardous waste (Nolz, Absi, \& Feillet, 2014), for example, infectious medical syringe, to reduce public health risks. Figure 3 illustrates the various research scopes found in CSC. 


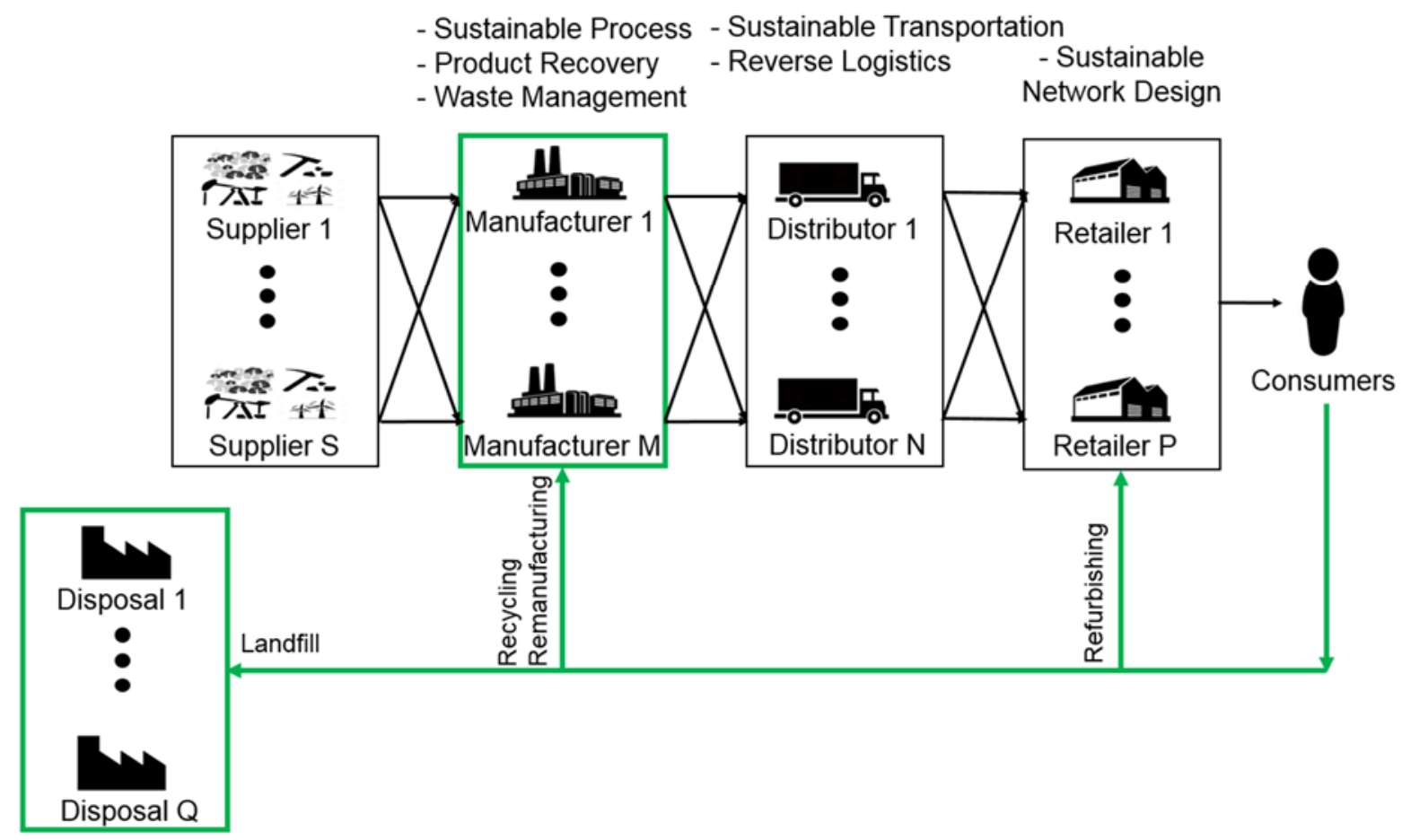

Figure 3. Research conducted in the circular supply chain area

\subsection{Sustainable Circular Supply Chain}

Reducing waste and need for virgin raw materials are the provided justifications for this assumption that CSC is inherently sustainable (Melachrinoudis, 2011; Srivastava, 2008). The validity of this claim is under question unless CSC supported not only the reverse logistics activities but also the design of green products. Accordingly, the next generation of CSC, sustainable CSC, achieves the best socio-environmental values in alignment with the value circle, from value proposition (i.e., designing green products), to value delivery and creation (i.e., incentivizing for going circular), and value capture (i.e., Reduced environmental burden) (Geissdoerfer et al., 2018).

Value proposition focuses on offering sustainable products and services to ensure profit and minimize socio-environmental impacts while value creation is handled via incentivizing actors to collect and return disposal (Accorsi, Manzini, Pini, \& Penazzi, 2015; Mota, Gomes, Carvalho, \& Barbosa-Povoa, 2018).

Sustainable/green product design is now seen as the leading strategy for saving resources and reducing adverse eco-effects (Leigh \& Li, 2015). Various potential designs of a product along with different configurations of supply chains should be analyzed to come up with the optimal product design. Generally, product design strategies can be categorized into two streams:

(i) Designing products with the application of cleaner production principles to decrease environmental impacts and resource dependency, known as design for material efficiency and sustainable production (Stindt, 2017). 
(ii) Designing products that have longer life cycle and can be easily taken apart at the end of life so that these parts can be reused, called design for sustainable usage and design for recovery (Stindt, 2017).

In the former strategy, the harmful or resource dependent components of a product are identified and replaced with eco-friendly materials (Hassini, Surti, \& Searcy, 2012). This strategy requires significant investments as new cooperation with green material suppliers may need to be established and new technologies for processing these materials and producing environmentally friendly products need to be implemented. The new design is to reduce toxic use, waste and necessity for post-use treatment. The latter strategy, however, tries to preserve the inherent value of products for as long as feasible. The objectives of this strategy are compatible with the preventive design strategy but the focus shifts to enhanced durability, product-service combinations, updatability via software upgrades, or manufacturability approaches (Munasinghe, Jayasinghe, Ralapanawe, \& Gajanayake, 2016). Here, the products are designed for remanufacturing, disassembly or recycling. Such products can be easily, cost-effectively and rapidly dismantled in their post-use phase so that parts can be either reused or recycled (Bansal, 2005). The waste management policies and availability of appropriate technologies can explicitly influence the success of this strategy. For instance, governmental regulations, such as a fee on disposal and waste takeback, in which manufacturers are responsible for collecting and treating their end of life products, motivates the adoption of design for disassembly strategy (Tang \& Zhou, 2012). Similarly, investment should be made in technologies that increase the re-manufacturability of returned products. Technology selection decisions should be taken not purely in accordance with the economic and technical factors (e.g., production costs, process flexibility), but also with socio-environmental factors (e.g., rate of waste generation, energy consumption, safety index, etc.) (Tang \& Zhou, 2012). Examining the sustainability impacts of adopted technologies is an important lever for supply chains involving sustainability improvements (Tang \& Zhou, 2012).

Addressing the socio-environmental impacts of products has become one of the main design challenges in the last two decades. Thus, in the first step of green design, the footprints of a given product are analyzed across its entire life cycle, from the point of origin to the point of production-consumption and post-consumption. This provides designers with important information regarding the potential hotspots for resource savings or pollution reduction in the production cycle (Munasinghe et al., 2016). According to the identified hotspots, supply chain decisions are made with respect to the design strategies and possible improvements in the operations. Life cycle assessment methodologies such as life cycle assessment (LCA) and social life cycle assessment (sLCA) are appreciated as tools for quantifying the sustainability impacts of various products, processes and industrial systems for both research and practical needs (De Luca et al., 2017). It is noted by many scholars that green product design is linked to the product LCA results. These results highlight the most impactful areas of a product life cycle and help researchers to determine potential improvement scenarios to reduce impacts (De Luca et al., 2017).

LCA evaluates the environmental impact of a given product, from raw materials extraction through to production and recycling/incineration along its life. There is a growing consensus on the use of LCA approach in SSC studies as an objective methodology for appraising different typologies of environmental impact Since the LCA approach offers a broader 
environmental impact analysis throughout the product life cycle and allows for comparisons of various products, it fits well within the discourse on sustainability (De Luca et al., 2017). In addition, sLCA aims at quantifying the social impacts derived from many different factors during each life cycle phase of a product.

Despite the usefulness and popularity of the LCA approach, its full implementation hugely depends upon the nature of given products and the standardization level of the production process (De Luca et al., 2017). Although LCA evaluations have already been conducted for a wide range of products, in some cases we run into methodological challenges. These challenges are related to defining the functional unit, collecting data or analyzing the inventory. For food and agricultural products, as an example, data collection under various farming systems (organic or non-organic), climatic factors and local environmental elements (e.g., soil type, water availability) requires much effort (De Luca et al., 2017).

In case of sLCA, there is no consensus among researchers regarding the social impacts assessment. On the one hand, due to lack of methodological standardization, there is neither an agreed structure nor a unique evaluation process for the sLCA approach (De Luca et al., 2017). On the other hand, a clear definition of social responsibility has not been proposed mainly because it has a multi-disciplinary and multi-stakeholder nature (Chaabane, Ramudhin, \& Paquet, 2012). Therefore, the incorporation of sLCA into SSC studies faces many challenges and its full implementation is still not practically possible (Popovic, Barbosa-Póvoa, Kraslawski, \& Carvalho, 2018).

For these reasons, in many papers on sustainable CSC, researchers are likely to use partial LCA methodologies. Depending on the characteristics of the products that are to be investigated, this method focuses only on the most impactful environmental impacts categories or covers particular life cycle stages (e.g., cradle to gate versus cradle to cradle to undertake the assessment (Eskandarpour et al., 2015). Acidification, eutrophication, global warming, ozone depletion, photochemical ozone creation, and energy use are the big six impact categories of LCA.

Despite the popularity of partial assessments, a number of researchers questioned the validity of its results. Schlegel et al. (2016) criticized the results of partial assessment of road construction practices by comparing them to the results of more comprehensive assessments. Valuable sustainability outcomes can be lost and wrong environmental decisions may be made, if a predefined, limited set of environmental or social indicators are used for impact assessment (Michelsen, Fet, \& Dahlsrud, 2006). To address this concern, participatory life cycle sustainability assessment (LCSA) framework was developed recently to partially assess the impacts that are most important for particular groups of stakeholders. LCSA is an aggregation of LCA, SLCA and life cycle costing methodologies devoted to comprehensive sustainability evaluation. Participatory approaches in this framework refer to those techniques and methods (e.g., multi-criteria decision making, multi-attribute utility theory, etc.) that allow the involvement of stakeholders, particularly those who are affected by the impacts of products and processes (Ekvall, Ljungkvist, Ahlgren, \& Sandvall, 2016; Guijt, 2014). The involvement of participatory approaches in LCSA enables stakeholders to decide on assessment scope, indicators, weights and aggregation methods (De Luca et al., 2017). The practical use of comprehensive approaches for measuring the effectiveness of 
supply chain like participatory life cycle sustainability assessment is to be considered more in future research. Figure 4 summarizes the issues that are described in the text above.

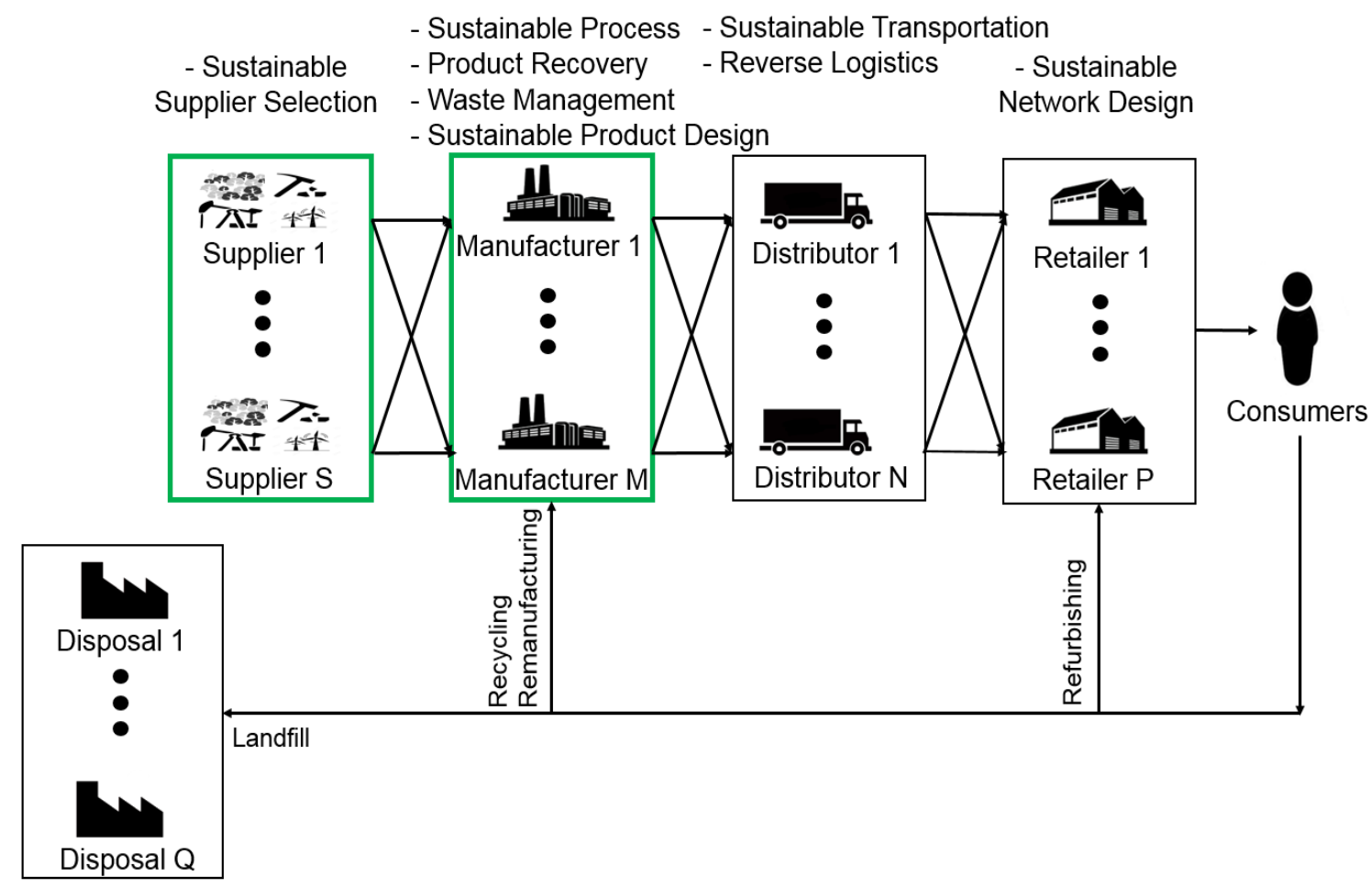

Figure 4. Scope of sustainable circular supply chains

\section{Towards the ESSC Conceptual Framework}

\subsection{Sustainability and Financial Performance}

The relationship between the efforts towards making SC sustainable (including SSC, CSC and sustainable CSC) and their financial performance has been investigated in a large body of literature (see review by de Oliveira, Espindola, da Silva, da Silva, and Rocha (2018)). The results are contradictory: some studies found efforts towards sustainability in supply chains as financial burdens, whereas, others reported increased profitability and competitiveness (Wu \& Pagell, 2011).

Environmental efforts such as minimization of resource consumption and reducing the fossil fuel consumption do reduce the costs and increase profits but may require upfront investments. The implementation of green technology, designing green products, and going circular are not quite aligned with cost-saving objectives. The investments in new design and technologies may take a long time to get paid off. Longer returns on technology investment put the financial health of the supply chain at risk (Mathiyazhagan, Govindan, NoorulHaq, \& Geng, 2013). Munasinghe et al. (2016) found that adjusting an already existing supply chain to produce new low carbon products was more costly and difficult compared to designing the appropriate production processes from scratch. Xia, Govindan, and Zhu (2015) report that in most small and medium size supply chains, funding for research on design for disassembly or remanufacturing is often cut and reverse logistics activities are limited to waste management. Also, other expenses related to green upgrades, such as energy efficient 
machinery and green materials tend to increase the total cost of products and ultimately the product prices (Eccles, loannou, \& Serafeim, 2014). Therefore, for many supply chains that took steps towards sustainable development, costs have become a big concern (Bhanot, Rao, \& Deshmukh, 2017).

Substantial upfront costs required for initiating a green revolution affect the financial strength and pure profit margins of supply chains adversely, at least in short term. The reduced financial performance and eroded competitive advantages causes uncertainties in stakeholders' decisions for going green, as the promise of improved benefits does not come true immediately (Nidumolu et al., 2009). Therefore, the major challenge facing supply chains is how to compensate for the increasing costs of transition towards sustainable SSC.

Despite the warnings by Pagell and Shevchenko (2014), most of the papers are still talking about financial gains and losses only in monetary terms. We argue that by incorporating societal preferences and norms into the SSC analysis, we have a better chance to account for other drivers that may not immediately translate into purely financial measurements. Decisions, like closing the resource loop or greening different processes, create a green image of the supply chain (Park, Sarkis, \& Wu, 2010). The positive relationship between green image and environmental performance (Rao \& Holt, 2005) lead to enhanced competitive advantage, sales and market share, profit margins and superior economic performance (Schrettle, Hinz, Scherrer-Rathje, \& Friedli, 2014). This immediately calls for deeper considerations of consumer behavior and how it can impact the overall success of the SC. People will be buying certain goods not only because they deliver more functionality for a lower price, but because they approve how they were produced and delivered, because they appreciate the SSC, no matter what the monetary costs are. Researchers highlighted that sustainable SSCs can both minimize socio-environmental impacts and maximize financial benefits (Zhu \& Sarkis, 2004). However, it is difficult to come to a clear conclusion because of changing market rules, varying regimes of taxation and subsidies. These in turn depend on governmental policies and decisions (Li, Chen, Xu, \& Hou, 2018), further raising the importance of accounting for the consumer preferences and choices at the ballot boxes. Unless the social processes and dynamics are part of the analysis, we will not be able to account for all the delicate feedback effects and non-monetary metrics.

\subsection{Sustainability and Consumer Behavior}

Excessive use of natural resources to provide for ever-increasing irresponsible consumption of products and services in recent decades have prompted environmental degradation worldwide (Chen \& Chai, 2010). Consumption patterns and consumer preferences have a significant impact on environmental deterioration (Biswas \& Roy, 2015), and attracted attention of several researchers who study green consumer behavior. A set of terms such as green, eco-conscious, sustainable, responsible, and pro-environmental behavior have been used to define consumers' care for the environment (Kumar \& Polonsky, 2017). However, consumer behavior has been receiving little attention in the context of supply chains. The few examples that we found include Pankaew and Tobe (2010), who studied whether the greenness was a selection criterion for electronic device consumers, and Dan-li, Zhen, and Hong-yan (2011), who demonstrated that the demand of consumers could be shifted towards green products by adopting competitive price strategies. Coskun, Ozgur, Polat, and Gungor (2016) proposed a model for the green supply chain network design based on consumers' green expectations. 
Making changes in diet, taking energy conservation measures, and managing and recycling waste are a few examples of desirable pro-environmental behavior change. Some people choose to ignore the environmental impacts of their purchases and explain the negative environmental messages about products to marketing attempts. They undermine the green products value and question whether a green product is worth the higher price. Changing the irresponsible behavior of this group is hard, just like changing any other human behavior.

A wide-range of complex factors influence environmentally responsible purchasing and eco-conscious behavior. These factors can be generally classified as individual factors and situational factors (Joshi \& Rahman, 2015). Individual factors related to green behavior are derived from the individual's personal traits, cultural norms, education, subjective knowledge, and life experiences. Individual factors including environmental concerns and responsibility, perceived consumer effectiveness, perceived behavioral control, values and personal norms, and knowledge positively influence green consumption behavior (Groening, Sarkis, \& Zhu, 2018). However, environmentally damaging habits and lack of trust in green products can deter individual actions toward ecologically-conscious consumption behavior. Situational factors are concerned with the circumstances and situations in which a person makes decisions (Joshi \& Rahman, 2015). Situational factors such as product price, availability of products and alternatives, social norms and reference groups, product quality, store related attributes (e.g., size, location, etc.), brand image, eco-labeling, and certifications can impact pro-environmental consumer behavior (Joshi \& Rahman, 2015). All these individual and situational factors can discourage or encourage green purchase behavior, but the extent to which they influence sustainable behavior requires further research.

While the rate of environmental degradation is rapidly increasing, the changes of individual behavior to more sustainable purchasing practices are much slower (Taufique \& Vaithianathan, 2018). Thus, after identifying the causal factors of a particular green behavior, it is necessary to adopt intervention strategies that target the promotion of relevant behavioral factors. A set of various strategies for different behavior determinants have been proposed to promote green changes. They are broadly classified into informational and structural strategies. The former are aimed at changing the individual factors of green behavior (e.g., green concern, knowledge, personal norms), whereas, the latter focus on the situational factors influencing environmental behavior (e.g., price, availability, social norms) (Abrahamse, Steg, Vlek, \& Rothengatter, 2005). Prompts and information campaigns, individualized social marketing, social support and role models, public involvement and participatory approaches are examples of effective informational strategies for the adoption of pro-environmental behavior (Steg \& Vlek, 2009). Structural strategies are associated with, for instance, providing better behavioral options, making environmentally harmful behavior less feasible or infeasible, rewarding good and punishing bad behavior, and proposing financial and legal measures (Steg \& Vlek, 2009). The effectiveness of these strategies in orienting people's behavior towards greenness depends on the characteristics, motivation, regional culture, and situation of different target groups.

Consumer behavior shows not only in the purchasing decisions that are made, but also impacts the governmental performance and the policies that are delivered. These in turn feed back into human behavior. The impact of government policies on pricing of eco-friendly products ( $\mathrm{Li}$ et al., 2018) and waste management (Zand, Yaghoubi, \& Sadjadi, 2019) has been well documented and only confirms importance of close integration of social, behavioral aspects into the SSC analyses. 
What is most important, and what we see from the overall effectiveness of various commercials and advertisement methods, is that changing consumer preferences and behavior is possible, and it would be inappropriate to ignore or overlook it when designing and managing supply chains in a sustainable way.

\subsection{Extending Circular Supply Chain for Sustainability}

Much of the supply chain success depends on the extent to which it is capable of predicting and meeting customer expectations. One of the principles of supply chain management is that customer demand drives the entire supply chain, pulling products through production and distribution processes. The demand-driven supply chain or customer-centric supply chain terms resulted from customer-focused thinking approach. Likewise, in today's green economy, environmental needs of consumers have profoundly influenced the disposition of supply chains for transition towards SSC. In fact, the pro-environmental behavior of supply chains is guided by customers' attitude towards eco-friendly products. That is to say, the consideration of green consumer behavior in the management of involved companies on the supply chain is critical (Lacoste, 2016).

Paying attention to consumer demand and preferences is crucial for addressing sustainability. We cannot claim that a supply chain is sustainable unless we consider both the impacts on natural resources and the society. Consumer preferences are key to making sure that supply chains are modified to take into account sustainability issues. Without additional support and incentives from consumers, it is unlikely that SSC can be competitive and financially viable. Consumer choices and their willingness to pay more for green products can make sustainable products more competitive. The focus on sustainability in SC can, in turn, influence consumer behavior and raise their awareness about socioenvironmental concerns. We, therefore, propose a conceptual framework (see Figure 5) to emphasize the importance of consumers and their green behavior for sustainability features of supply chains.

The "Extended Sustainable Supply Chain" (ESSC) can be considered as an extension to the traditional concept of sustainable circular supply chain that includes behavioral aspects of consumers. ESSC is motivating sustainable consumer behavior to drive decision-making process along the whole SC for improving socio-environmental performance. By extending the supply chain analyses to include consumer behavior we may be entirely changing the goals/objectives used in the supply chain optimization efforts, and, therefore, affecting the performance of the supply chains. If consumers are motivated to switch from purely economic cost/benefit considerations when making their purchase decisions, and start to bring in additional considerations about environment, social and intergenerational justice, ecological and human health, etc., then these preferences start to feed back into the design and organization of the supply chain. As a result, we will likely see very different solutions and investment strategies becoming dominant. 


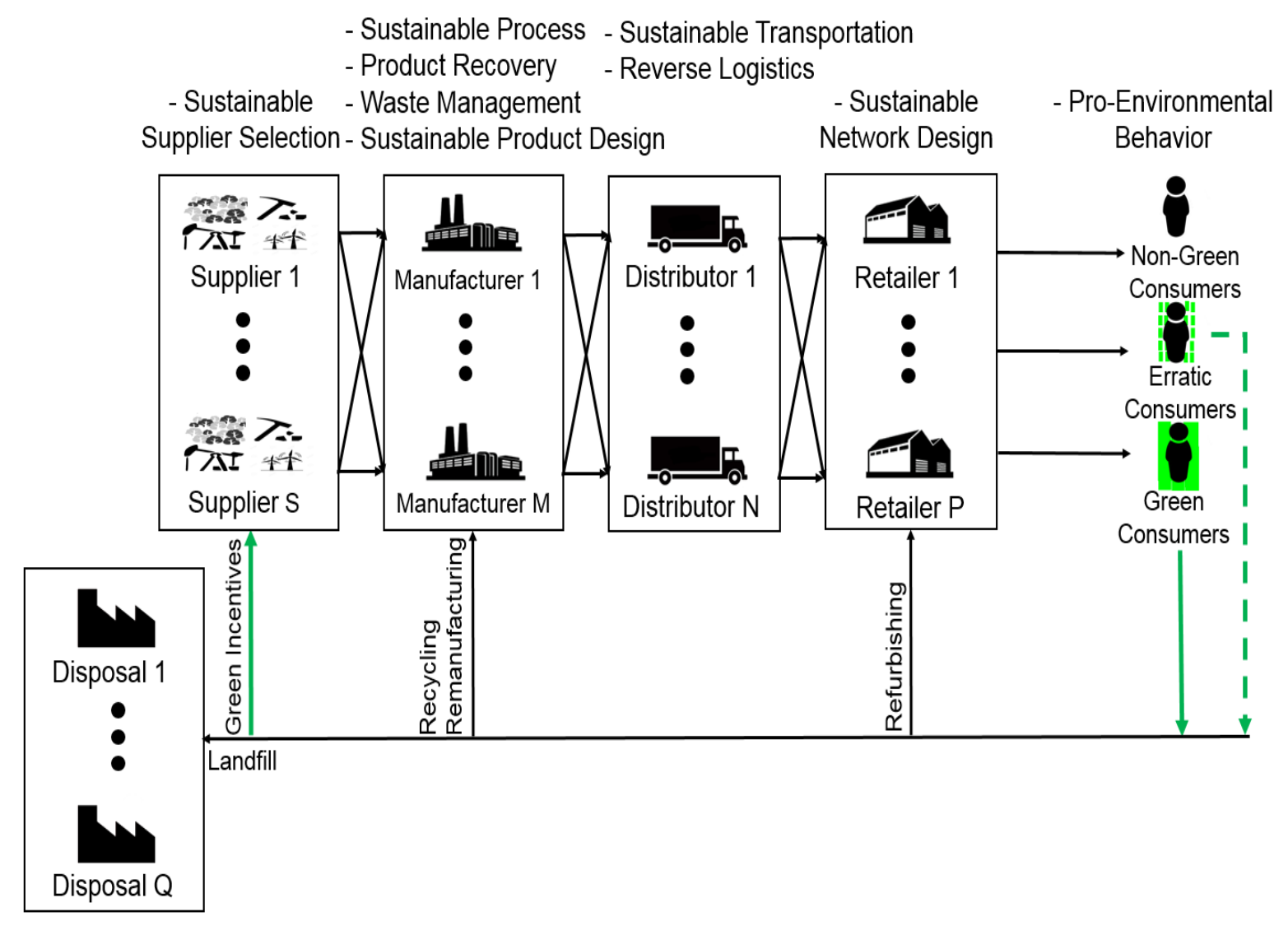

Figure 5. Extending circular supply chain to address sustainability (ESSC framework); where —represents the feedback from green consumers and - - - represents the feedback from erratic/uncertain consumers

As discussed above (see section 2), SSC literature had no (as in traditional SSC) or poorly defined relationships (as in CSC and sustainable CSC) between upstream firms and final consumers, making it difficult for suppliers (i.e., manufacturer, distributor, etc.) to perceive and influence green consumer expectations (Lacoste, 2016). Also, the results of literature analyses show that green consumer expectations have been either left out of consideration entirely or just touched upon (Govindan, 2018; Tseng \& Hung, 2013).

Current SSC studies assume that consumers make entirely informed choices based on rationality. So far, rational behavior optimization and immediate equilibrating process in markets are used for demand modelling which is very different from the way consumers actually behave. The growing literature in social science emphasizes that many issues in consumer pro-environmental behavior are complex (Bamberg, Rees, \& Seebauer, 2015); that the choices the consumers make are influenced by behavioral factors (e.g., attitudes, norms) rather than the more predictable rationality. Underestimating these factors, analyses of market changes can be misleading. This is especially important in the context of sustainability, which is a largely social concept and assumes that consumers can substantially change their preferences, values, and behavior. Consumers can be influenced by information (awareness campaigns, targeted advertisement), they can learn from the behavior of other consumers (neighborhood effects). These changes, in turn can significantly modify demand and drive the whole SC. These aspects are largely ignored in existing research on SC. 
In the ESSC framework, the customer behavior is considered through identifying different market segments and influencing their green purchasing behavior. The results of market segmentation in regards to sustainability shows three general categories of green, erratic, and non-green consumers. Green consumers pay significant attention to socioenvironmental, as well as health impacts of products during use and post-use. Erratic consumers have some level of environmental awareness and intention, which might or might not lead to a green behavior. Non-green consumers, buy products with no concern for their environmental or social impacts, making their choices based only on their selfish cost/benefit considerations, or simply lacking information and awareness about the sustainability issues.

The sustainability efforts of suppliers, manufacturers, distributors and retailers should be adjusted to meet the expectations of each segment. Not only meeting each particular demand is the ultimate objective, but ESSC aims to see how this demand is formed and how it can be modified to increase the market share of green consumers and decrease the negative socio-environmental impacts. Factors affecting green consumers purchasing behavior and intervention strategies were discussed above in Section 3.2. With this setting, supply chains can reduce the resistance of partner organizations to change their unsustainable approaches and initiate their transformation efforts towards sustainable development. Just like advertisement is largely responsible for creating the current consumer society, similar efforts, but probably in the opposite direction, are required and should be expected if we are to move toward sustainability.

As we discussed in Section 3.1, many supply chains that begin their journey towards sustainability are hesitant about making changes because of concerns about their profitability after the transition. Green materials, for instance, tend to be more expensive (Wu \& Pagell, 2011). Replacing hazardous materials with them would raise the overall cost of production and prices of final products (Beske, Koplin, \& Seuring, 2008). However, if consumers are willing to pay more for the green products, the extra cost will be transferred to them and compensated for the producers. At the same time, we should be prepared that while paying higher per unit prices, consumers may be inclined to decrease the overall number of units to be purchased, which will certainly impact the overall performance of the SC.

Consider the following cases in food and garment production. In a food supply chain, if consumers are persuaded that organic, ethical food (i.e., fair trade (O'Connor, Sims, \& White, 2017)) are better for health, environment, society, and thus worth the extra cost, they will be then willing to pay a higher price for such products (Rödiger \& Hamm, 2015). By doing so they provide financial support for mitigating the risks involved in organic food supply chain. These risks are not only limited to real physical risk (e.g., threat of pests destroying crops) but also they are related to the costly process of getting certified (at least 750 USD in the United States) and timely conversion from conventional to organic farm (approximately 3 years). According to the International Federation of Organic Agriculture Movements (IFOAM) and Food and Drug Administration (FDA) regulations, organic food producers are responsible for meeting sustainability requirements in all supply chain stages, from farm management and transportation, to storage and packaging (Marques Vieira, Dutra De Barcellos, Hoppe, \& Bitencourt da Silva, 2013). Because of the high risk of organic food contamination, it cannot be carried with other food in trucks and cannot be stored together with conventional food. This may lead to an increase in complexity of logistics and supply 
chain management as additional provisions are required for organic product transport. Garment industry is another example showing how changing consumer behavior can address environmental issues of supply chains. Raw material production is reported to be the most environmentally impactful phase of garment life cycle (Bevilacqua, Ciarapica, Giacchetta, \& Marchetti, 2011). However, research showed that garment usage phase which is dependent upon the customer behavior could be even more harmful. In particular, for sensitive fabrics, washing followed by drying and ironing was the most energy-intensive activity (Dewaele, Pant, Schowanek, \& Salducci, 2006). Changing washing habits can reduce carbon emissions by $2 \%$ and energy by $4 \%$ per product (Munasinghe et al., 2016). The eco-friendly behavior of consumers can be extended to promote recycling. Textiles are then recovered and reused so that the dependency on virgin materials (i.e., cotton) is reduced and environmental performance is improved. Using cold-water detergent and washing machines at lower temperature settings provide another significant opportunity to reduce environmental impacts. The result of an LCA study on lowering washing temperature from $32{ }^{\circ} \mathrm{C}$ to $15{ }^{\circ} \mathrm{C}$ has shown a $300 \mathrm{~g}$ reduction in $\mathrm{CO} 2$ equivalent per load as less energy was consumed to heat water (Nielsen, 2005). Although using cold water can save money (\$US 60 - 200 per year) and energy (GHG equivalent to 1000 miles of driving), some consumers do not perceive washing at cold temperatures hygienic (Mars, 2016). Thus, increasing consumer awareness about the effectiveness and safety of cold-water washing is necessary to address their concerns and promote energy-saving habits.

These examples show how by raising consumer awareness and motivating behavioral shifts, the impacts of supply chains on environment are reduced. When turning conventional supply chains into sustainable supply chains behavioral changes may deliver as much economic and environmental efficiency as all the other technological/methodological developments in the field. Because of the multitude of feedback effects between the operation of the supply chain and the consumer behavior, we suggest that the two are integrated and considered jointly within the framework of ESSC, rather than bringing in considerations about consumers at the end assuming them to be beyond the SC analyses.

\subsection{Application of ESSC in Practice}

In this section, we apply our proposed conceptual framework in two case study settings, forward SSC and sustainable closed loop SC. For each case, we explain how economic and socio-ecological performance can be improved if the companies revisit their practices in accordance to ESSC framework.

\subsubsection{Extending a SSC for Bicycles}

Park, Kremer, and Ma (2018) proposed a SSC model focusing on sustainable supplier selection and optimal order allocation. They aimed to minimize total cost, defects, delivery delays and carbon footprint of global supply chains. In this study, initially, a set of supplier regions (countries) were determined based on regional sustainability indices and then the final suppliers were selected from the list of candidate regions. The performance of the model was demonstrated in a bicycle SC case study with a budget of $\$ 9$ million to meet a demand of 12,000 units. Their analysis indicated that the optimal solution reached $75.6 \%$ or $77.3 \%$ of the ideal solution if the decision maker gave higher values to cost or environmental impact objectives, respectively. Although environmental impact-oriented strategy had the 
best carbon reduction performance (dropped from 2,130,176.63 $\mathrm{kg}$ CO2 equivalent to $1,849,144.51 \mathrm{~kg} \mathrm{CO} 2$ equivalent), the total SC cost was significantly higher (growing from $\$ 7,234,691.92$ to $\$ 5,999,539.12$ ). They concluded that the consideration of sustainability in SSC can be challenging.

We suggest using ESSC framework to address this challenge through applying behavior change to increase the number of people cycling, which eventually will increase the demand for bicycles. Biking is one of the most sustainable means of transportation. The estimated climate impact of riding a bicycle is 40-65 ( $\mathrm{g} \mathrm{CO} 2 /$ passenger $/ \mathrm{km})$ while driving a car has an impact of 300 (g CO2/passenger $/ \mathrm{km}$ ) (Thorpe \& Keith, 2016). Using a bicycle for trips of up to 10 kilometers (each way) can save $1500 \mathrm{~kg}$ greenhouse gas emissions per year per individual (Queensland Government- Department of Transport and Main Roads, 2018). Increasing education, awareness, effective communication and social support as well as reducing the perceived risks of cycling can motivate people to change their behavior and start riding on a regular basis. For example, management and regulations could be directed towards increasing the connectivity and safety of cycling routes and raising awareness about the benefits of cycling for the rider (e.g., healthy lifestyle, burning calories, saving transportation costs) and for the society (e.g., less road traffic, less need for fuels, more carrying capacity of public transport). As a result of such measures, the proportion of people in the City of Sydney, Australia, who have ridden their bicycle to work have doubled in a 10 year period (2006-2016) (NSW Government- The City of Sydney, 2018).

Such practices as organizing events (e.g., speed dating, charity rides), providing cycling courses and informational campaigns, or funding projects for improving the usability, accessibility, and attractiveness of biking can be considered as parts of the bicycle ESSC to develop a more profitable, environmentally-friendly and socially-favorable business.

\subsubsection{Extending an SCSC for Tire Production}

Sahebjamnia, Fathollahi-Fard, and Hajiaghaei-Keshteli (2018) designed a SCSC model to address supplier selection and location-allocation problems for the tire industry. The sustainability objectives were defined as minimizing total network costs and total environmental impacts as well as maximizing social benefits. The market demand for different tire types and the fraction of used tires returned from market were assumed to be deterministic and unchanging. They numerically showed that if the amount of collected and recycled tires are increased, the total costs of economic considerations will decrease and the social impacts (due to availability of more job opportunities) will improve. In this study, no explanation was given to understand how the number of scrapped tires is to be increased, how consumers can be motivated to return their products back to the collection/distribution centers and what dynamics are involved in consumer behavior. The ESSC framework can address this gap by suggesting to use behavior change strategies to motivate waste recycling decisions of consumers. In Figure 6, we demonstrate how can Sahebjamnia et al. (2018) CSC framework be extended. 


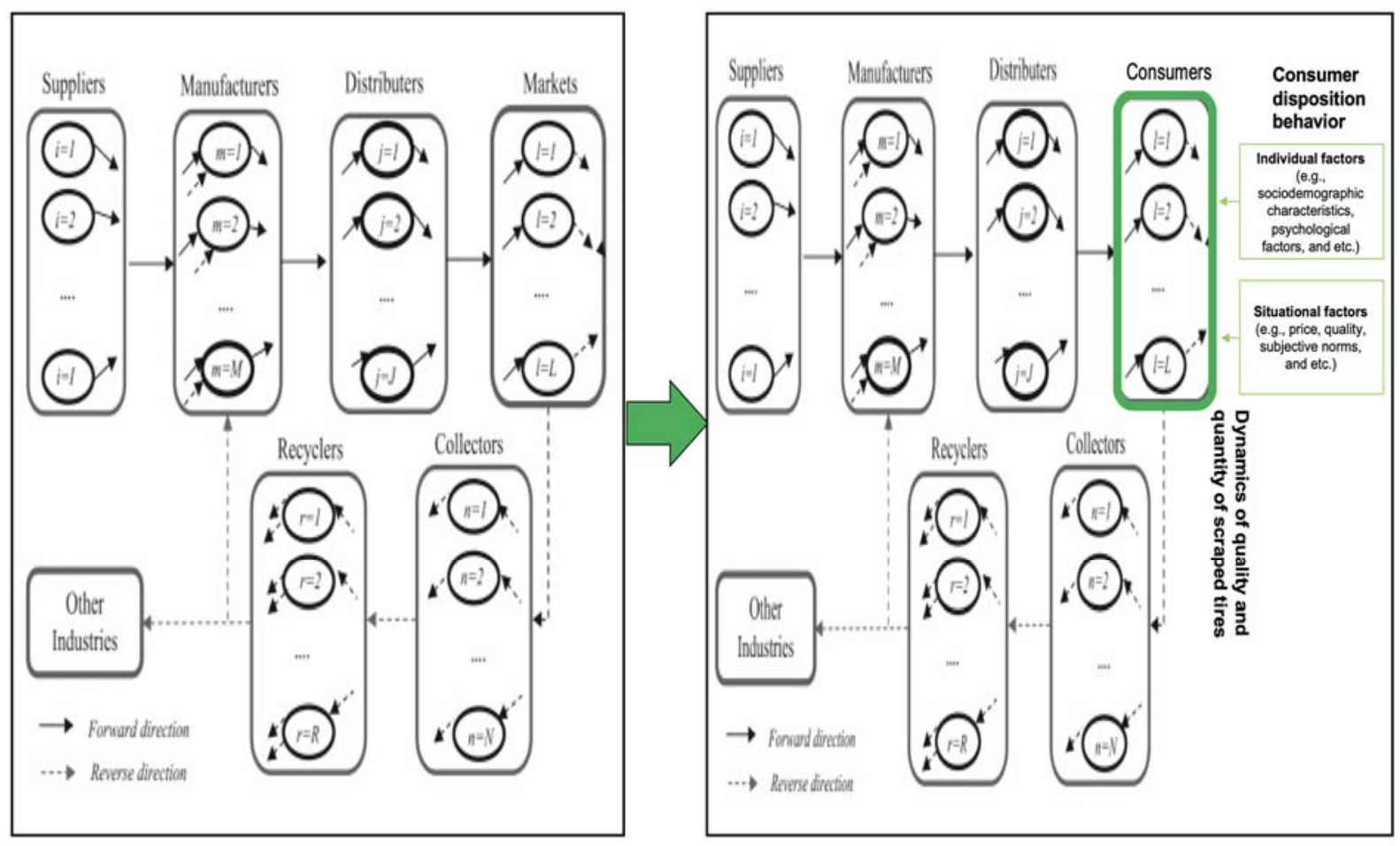

Figure 6. Comparison of tire closed-loop supply chain network developed by Sahebjamnia et al. (2018) (left hand side) and proposed tire extended closed loop supply chain (right hand side). We suggest replacing markets agent with consumers agent to investigate used tire disposal behavior of consumers

For designing appropriate change strategies, we first need to identify what individual and situational factors influence the disposition behavior. Gaur et al. (2016) categorized these factors as psychological, product-related, situational, and cultural. They highlighted that in many cases, lack of information about take-back policy of companies, absence of financial incentives, and poor access to collection centres are the main reasons discouraging consumers to return the used products. Considering both the individual and situational behavioral factors, the suggested framework gives a more realistic understanding of the product acquisition process for remanufacturing. The quality and quantity of returned tires can be increased if the company makes the return process easy by offering free shipping, locating collection centres close to consumers, providing financial/non-financial incentives for returns, informing consumers about the return policies, or creating a local culture for recycling through education and information campaigns. Effective product return strategies can result in higher profitability of the company, lower environmental impacts, and cheaper remanufactured products for the consumer.

\section{Conclusions and Outlook}

In this paper, we suggest that an extension of the supply chain concept is needed if we want to analyze their sustainability. First, we present an overview of the evolution of the SC concept with respect to sustainability goals. To this end, we select some most relevant papers and critically compare and contrast them. Summarizing literature on sustainable supply chains, circular supply chains and sustainable circular supply chains, we show why they were not quite adequate to address the holistic and system wide sustainability issues. 
We discuss the sustainable forward logistics issues in SSC and the integration of circular economy concepts with the supply chain organization. The relationship between LCA methodologies and CSC is examined in the context of sustainable CSC. This review clearly demonstrates how the SC concept has been evolving to include additional processes and actors, to consider the requirements of sustainable development.

Next, we show how financial performance of supply chains may be influenced as a result of implementing green practices such as green technology, green product design, and end of life treatment. Most supply chain managers conclude that their competitiveness is eroded with increases in the cost of green products. Furthermore, we explain consumer choice behavior in purchasing green products and strategies to motivate pro-environmental behavior. By doing so, we set the foundation to consider the role of green product consumers in SSC.

To address sustainability in future research on SC we propose a conceptual framework which links three very different areas (i) supply chain design and engineering, (ii) financial performance, accounting and economic optimization and, (ii) consumer behavior and environmental psychology. Figure 7 shows the evolution of sustainable supply chain concept in literature and how we think it should further develop. Our findings demonstrate how financial performance of SSC can be improved by bringing the consumer into the picture and exploring how their willingness to pay and sustainability concerns can be influenced and modified. Although it is important for the focal firms to identify possible strategies for motivating pro-environmental behavior of stakeholders, particularly consumers, SSC studies are still far from providing comprehensive analytical studies. Disregarding the relations between SSC and consumer behavior leads to a blurred notion of sustainability in supply chain research. From a theoretical perspective, we argue that for transition towards sustainability, it is crucial to take the extended supply chain view, in which the boundaries are expanded towards the involvement of consumers and their behavior.

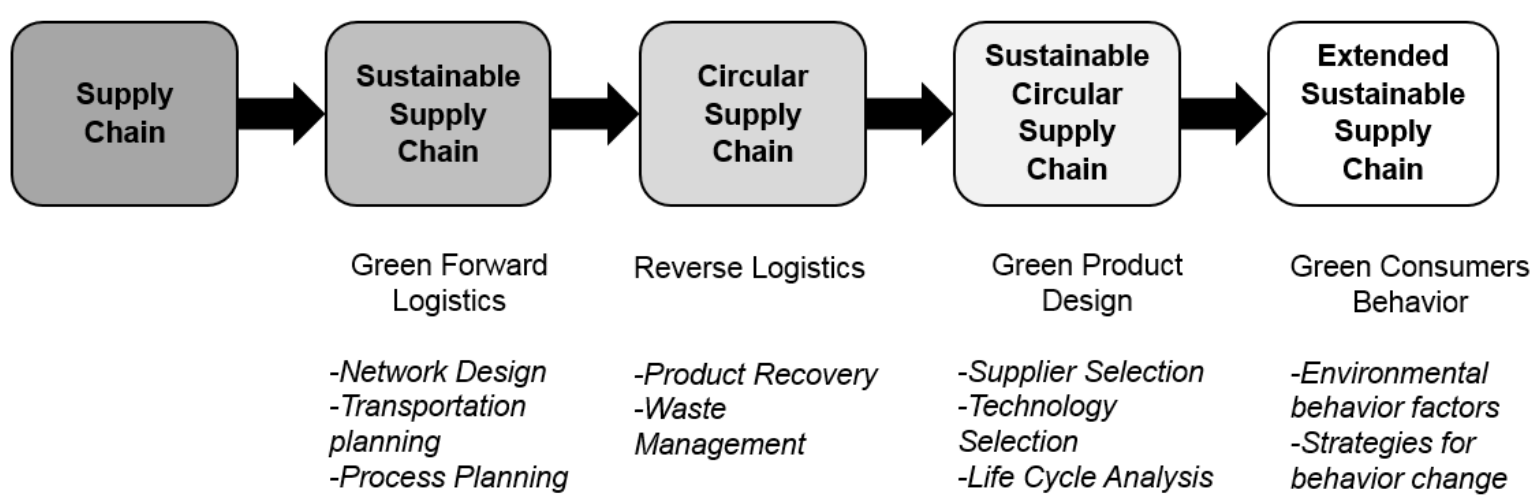

Figure 7. Comparison of scopes for conventional, green, sustainable and extended supply chains

We invite sustainable supply chain analyses to go beyond their tradition scope of operations, and bring consumer behavior dynamics into consideration. It is important to identify the factors influencing consumer choice behavior regarding sustainable products and apply appropriate interventions to change unsustainable consumer behavior. The growing 
field of behavioral and empirical economics and the proliferation of agent-based modeling methods, can now look at heterogeneous human behavior under various conditions, and can help understand and quantify some of the cultural and social drivers that affect SC (Filatova, Verburg, Parker, \& Stannard, 2013; Anufriev, Hommes, \& Makarewicz, 2018). These models can be well integrated with SSC models to include the social dynamics in SC design and management (Taghikhah, Voinov, \& Shukla, 2018). They can be used to improve SCM and offer additional control parameters for optimization of SC performance. The ESSC framework assumes that other managerial techniques should be also employed, with a focus on the social dimension, on education, motivation, nudging and persuasion as part of development towards sustainability.

We hope that the ESSC framework can help supply chains to become green and to gain competitive advantage and improve visibility of sustainable practices in the evolving marketplace. A future extension of this research will consist of developing analytical studies to compare the performance of extended sustainable supply chain with conventional frameworks. Another extension can be to empirically analyze the impact of adopting behavioral change strategies for green demand and green supply. Future studies can develop tools and models to deal with the difficulty of prediction and high uncertainties involved in behavioral aspects of green consumption.

\section{Funding sources}

This research did not receive any specific grant from funding agencies in the public, commercial, or not-for-profit sectors.

\section{References}

Abrahamse, W., Steg, L., Vlek, C., \& Rothengatter, T. (2005). A review of intervention studies aimed at household energy conservation. Journal of environmental psychology, 25(3), 273-291. doi:https://doi.org/10.1016/j.jenvp.2005.08.002

Accorsi, R., Manzini, R., Pini, C., \& Penazzi, S. (2015). On the design of closed-loop networks for product life cycle management: Economic, environmental and geography considerations. Journal of Transport Geography, 48, 121-134. doi:https://doi.org/10.1016/j.jtrangeo.2015.09.005

Ageron, B., Gunasekaran, A., \& Spalanzani, A. (2012). Sustainable supply management: An empirical study. International journal of production economics, 140(1), 168-182. doi:https://doi.org/10.1016/j.ijpe.2011.04.007

Ansari, Z. N., \& Kant, R. (2017). A state-of-art literature review reflecting 15 years of focus on sustainable supply chain management. Journal of cleaner production, 142, 25242543. doi:https://doi.org/10.1016/i.jclepro.2016.11.023

Anufriev, M., Hommes, C., \& Makarewicz, T. (2018). Simple forecasting heuristics that make us smart: Evidence from different market experiments. Journal of the European Economic Association. doi:https://doi.org/10.1093/jeea/jvy028

Bamberg, S., Rees, J., \& Seebauer, S. (2015). Collective climate action: Determinants of participation intention in community-based pro-environmental initiatives. Journal of environmental psychology, 43, 155-165. doi:https://doi.org/10.1016/j.jenvp.2015.06.006

Bansal, P. (2005). Evolving sustainably: A longitudinal study of corporate sustainable development. Strategic management journal, 26(3), 197-218. doi:https://doi.org/10.1002/smj.441 
Barbosa-Póvoa, A. P., da Silva, C., \& Carvalho, A. (2017). Opportunities and challenges in sustainable supply chain: An operations research perspective. European Journal of Operational Research. doi:https://doi.org/10.1016/j.ejor.2017.10.036

Bastas, A., \& Liyanage, K. (2018). Sustainable supply chain quality management: A systematic review. Journal of cleaner production, 181, 726-744. doi:https://doi.org/10.1016/j.jclepro.2018.01.110

Battarra, M., Erdoğan, G., \& Vigo, D. (2014). Exact algorithms for the clustered vehicle routing problem. Operations Research, 62(1), 58-71. doi:https://doi.org/10.1287/opre.2013.1227

Beheshtifar, S., \& Alimoahmmadi, A. (2015). A multiobjective optimization approach for location-allocation of clinics. International Transactions in Operational Research, 22(2), 313-328. doi:https://doi.org/10.1111/itor.12088

Bektaş, T., Demir, E., \& Laporte, G. (2016). Green vehicle routing. In Green transportation logistics (pp. 243-265): Springer.

Benjamin, A. M., \& Beasley, J. (2010). Metaheuristics for the waste collection vehicle routing problem with time windows, driver rest period and multiple disposal facilities. Computers \& Operations Research, 37(12), 2270-2280. doi:https://doi.org/10.1016/i.cor.2010.03.019

Beske, P., Koplin, J., \& Seuring, S. (2008). The use of environmental and social standards by German first-tier suppliers of the Volkswagen AG. Corporate Social Responsibility and Environmental Management, 15(2), 63-75. doi:https://doi.org/10.1002/csr.136

Bevilacqua, M., Ciarapica, F., Giacchetta, G., \& Marchetti, B. (2011). A carbon footprint analysis in the textile supply chain. International Journal of Sustainable Engineering, 4(01), 24-36. doi:https://doi.org/10.1080/19397038.2010.502582

Bhanot, N., Rao, P. V., \& Deshmukh, S. (2017). An integrated approach for analysing the enablers and barriers of sustainable manufacturing. Journal of cleaner production, 142, 4412-4439. doi:https://doi.org/10.1016/j.jclepro.2016.11.123

Biswas, A., \& Roy, M. (2015). Green products: an exploratory study on the consumer behaviour in emerging economies of the East. Journal of cleaner production, 87, 463468. doi:https://doi.org/10.1016/j.jclepro.2014.09.075

Bocken, N. M., de Pauw, I., Bakker, C., \& van der Grinten, B. (2016). Product design and business model strategies for a circular economy. Journal of Industrial and Production Engineering, 33(5), 308-320. doi:https://doi.org/10.1080/21681015.2016.1172124

Bouchery, Y., Ghaffari, A., Jemai, Z., \& Dallery, Y. (2012). Including sustainability criteria into inventory models. European Journal of Operational Research, 222(2), 229-240. doi:https://doi.org/10.1016/j.ejor.2012.05.004

Bouzembrak, Y., Allaoui, H., Goncalves, G., \& Bouchriha, H. (2013). A multi-modal supply chain network design for recycling waterway sediments. International Journal of Environment and Pollution, 51(1-2), 15-31. doi:https://doi.org/10.1504/IJEP.2013.053176

Boyacı, B., Zografos, K. G., \& Geroliminis, N. (2015). An optimization framework for the development of efficient one-way car-sharing systems. European Journal of Operational Research, 240(3), 718-733. doi:https://doi.org/10.1016/j.ejor.2014.07.020

Brandenburg, M., Govindan, K., Sarkis, J., \& Seuring, S. (2014). Quantitative models for sustainable supply chain management: Developments and directions. European Journal of Operational Research, 233(2), 299-312. doi:https://doi.org/10.1016/j.ejor.2013.09.032

Brandenburg, M., \& Rebs, T. (2015). Sustainable supply chain management: A modeling perspective. Annals of Operations Research, 229(1), 213-252. doi:https://doi.org/10.1007/s10479-015-1853-1

Bulmuş, S. C., Zhu, S. X., \& Teunter, R. H. (2014). Optimal core acquisition and pricing strategies for hybrid manufacturing and remanufacturing systems. International 
Journal of Production Research, 52(22), 6627-6641.

doi:https://doi.org/10.1080/00207543.2014.906073

Carter, C. R., \& Rogers, D. S. (2008). A framework of sustainable supply chain management: moving toward new theory. International journal of physical distribution \& logistics management, 38(5), 360-387. doi:https://doi.org/10.1108/09600030810882816

Chaabane, A., Ramudhin, A., \& Paquet, M. (2012). Design of sustainable supply chains under the emission trading scheme. International journal of production economics, 135(1), 37-49. doi:https://doi.org/10.1016/j.ijpe.2010.10.025

Chen, T. B., \& Chai, L. T. (2010). Attitude towards the environment and green products: Consumers' perspective. Management science and engineering, 4(2), 27-39.

Christopher, M. (2016). Logistics \& supply chain management: Pearson UK.

Chung, S. H., \& Kwon, C. (2015). Multi-period planning for electric car charging station locations: A case of Korean Expressways. European Journal of Operational Research, 242(2), 677-687. doi:https://doi.org/10.1016/j.ejor.2014.10.029

Clottey, T., Benton Jr, W., \& Srivastava, R. (2012). Forecasting product returns for remanufacturing operations. Decision Sciences, 43(4), 589-614. doi:https://doi.org/10.1111/j.1540-5915.2012.00362.x

Coskun, S., Ozgur, L., Polat, O., \& Gungor, A. (2016). A model proposal for green supply chain network design based on consumer segmentation. Journal of cleaner production, 110, 149-157. doi:https://doi.org/10.1016/j.jclepro.2015.02.063

Dan-li, D., Zhen, F., \& Hong-yan, Z. (2011). Research on the Price negotiation mechanism of Green Supply chain of manufacturing Industry from the angle of customer behavior. International Conference on Management Science and Engineering (ICMSE), $18^{\text {th }}$ Annual Conference Proceedings, 244-249, IEEE.

De Luca, A. I., Iofrida, N., Leskinen, P., Stillitano, T., Falcone, G., Strano, A., \& Gulisano, G. (2017). Life cycle tools combined with multi-criteria and participatory methods for agricultural sustainability: Insights from a systematic and critical review. Science of The Total Environment, 595, 352-370. doi:https://doi.org/10.1016/j.scitotenv.2017.03.284

de Oliveira, U. R., Espindola, L. S., da Silva, I. R., da Silva, I. N., \& Rocha, H. M. (2018). A systematic literature review on green supply chain management: Research implications and future perspectives. Journal of cleaner production. doi:https://doi.org/10.1016/j.jclepro.2018.03.083

Dehghanian, F., \& Mansour, S. (2009). Designing sustainable recovery network of end-of-life products using genetic algorithm. Resources, Conservation and Recycling, 53(10), 559-570. doi:https://doi.org/10.1016/j.resconrec.2009.04.007

Demir, E., Bektaş, T., \& Laporte, G. (2014). A review of recent research on green road freight transportation. European Journal of Operational Research, 237(3), 775-793. doi:https://doi.org/10.1016/j.ejor.2013.12.033

Desaulniers, G., Errico, F., Irnich, S., \& Schneider, M. (2016). Exact algorithms for electric vehicle-routing problems with time windows. Operations Research, 64(6), 1388-1405. doi:https://doi.org/10.1287/opre.2016.1535

Devika, K., Jafarian, A., \& Nourbakhsh, V. (2014). Designing a sustainable closed-loop supply chain network based on triple bottom line approach: A comparison of metaheuristics hybridization techniques. European Journal of Operational Research, 235(3), 594-615. doi:https://doi.org/10.1016/j.ejor.2013.12.032

Dewaele, J., Pant, R., Schowanek, D., \& Salducci, N. (2006). Comparative Life Cycle Assessment (LCA) of Ariel "Actif à froid"(2006), a laundry detergent that allows to wash at colder wash temperatures, with previous Ariel laundry detergents (1998, 2001). Procter \& Gamble, Brussels Innovation Center, Central Product SafetyEnvironmental, Brussels.

Du Pisani, J. A. (2006). Sustainable development-historical roots of the concept. Environmental Sciences, 3(2), 83-96. 
Eberle, U., \& Von Helmolt, R. (2010). Sustainable transportation based on electric vehicle concepts: a brief overview. Energy \& Environmental Science, 3(6), 689-699.

Eccles, R. G., loannou, I., \& Serafeim, G. (2014). The impact of corporate sustainability on organizational processes and performance. Management Science, 60(11), 28352857. doi:https://doi.org/10.1287/mnsc.2014.1984

Ekvall, T., Ljungkvist, H., Ahlgren, E., \& Sandvall, A. (2016). Participatory life cycle sustainability analysis. Report B2268. IVL Swedish Environmental Research Institute, Stockholm, Sweden.

Elkington, J. (2013). Enter the triple bottom line. In The triple bottom line (pp. 23-38): Routledge.

Elkington, J., \& Hailes, J. (1988). The green consumer guide: Penguin.

Eskandarpour, M., Dejax, P., Miemczyk, J., \& Péton, O. (2015). Sustainable supply chain network design: an optimization-oriented review. Omega, 54, 11-32. doi:https://doi.org/10.1016/j.omega.2015.01.006

Faccio, M., Persona, A., \& Zanin, G. (2011). Waste collection multi objective model with real time traceability data. Waste management, 31(12), 2391-2405. doi:https://doi.org/10.1016/j.wasman.2011.07.005

Fahimnia, B., Sarkis, J., \& Davarzani, H. (2015). Green supply chain management: A review and bibliometric analysis. International journal of production economics, 162, 101114. doi:https://doi.org/10.1016/j.ijpe.2015.01.003

Filatova, T., Verburg, P. H., Parker, D. C., \& Stannard, C. A. (2013). Spatial agent-based models for socio-ecological systems: Challenges and prospects. Environmental modelling \& software, 45, 1-7. doi:https://doi.org/10.1016/j.envsoft.2013.03.017

Gaur, J., Subramoniam, R., Govindan, K., \& Huisingh, D. (2016). Closed-loop supply chain management: From conceptual to an action oriented framework on core acquisition. Journal of cleaner production, 30, 1-10. doi:https://doi.org/10.1016/j.jclepro.2016.12.098

Geissdoerfer, M., Morioka, S. N., de Carvalho, M. M., \& Evans, S. (2018). Business models and supply chains for the circular economy. Journal of cleaner production, 190, 712721. doi:https://doi.org/10.1016/j.jclepro.2018.04.159

Geissdoerfer, M., Savaget, P., Bocken, N. M., \& Hultink, E. J. (2017). The Circular Economy-A new sustainability paradigm? Journal of cleaner production, 143, 757768. doi:https://doi.org/10.1016/j.jclepro.2016.12.048

Gimenez, C., Sierra, V., \& Rodon, J. (2012). Sustainable operations: Their impact on the triple bottom line. International journal of production economics, 140(1), 149-159. doi:https://doi.org/10.1016/j.ijpe.2012.01.035

Giunipero, L. C., Hooker, R. E., \& Denslow, D. (2012). Purchasing and supply management sustainability: Drivers and barriers. Journal of Purchasing and Supply Management, 18(4), 258-269. doi:https://doi.org/10.1016/j.pursup.2012.06.003

Global Agenda Council on Climate Change (2018). The global risks report. Retrieved from http://www3.weforum.org/docs/WEF GRR18 Report.pdf

Goetschalcks, M., \& Fleischmann, B. (2008). Strategic network design. In Supply chain management and advanced planning (pp. 117-132): Springer.

Govindan, K. (2018). Sustainable consumption and production in the food supply chain: A conceptual framework. International journal of production economics, 195, 419-431. doi:https://doi.org/10.1016/j.ijpe.2017.03.003

Govindan, K., Jafarian, A., Khodaverdi, R., \& Devika, K. (2014). Two-echelon multiplevehicle location-routing problem with time windows for optimization of sustainable supply chain network of perishable food. International journal of production economics, 152, 9-28. doi:https://doi.org/10.1016/j.ijpe.2013.12.028

Govindan, K., Soleimani, H., \& Kannan, D. (2015). Reverse logistics and closed-loop supply chain: A comprehensive review to explore the future. European Journal of Operational Research, 240(3), 603-626.

doi:https://doi.org/10.1016/j.ejor.2014.07.012 
Groening, C., Sarkis, J., \& Zhu, Q. (2018). Green marketing consumer-level theory review: A compendium of applied theories and further research directions. Journal of cleaner production, 172, 1848-1866. doi:https://doi.org/10.1016/j.jclepro.2017.12.002

Gruner, R. L., \& Power, D. (2017). Mimicking natural ecosystems to develop sustainable supply chains: A theory of socio-ecological intergradation. Journal of cleaner production, 149, 251-264. doi:https://doi.org/10.1016/j.jclepro.2017.02.109

Guijt, I. (2014). Participatory approaches. Methodological Briefs: Impact Evaluation, 5(5).

Hassini, E., Surti, C., \& Searcy, C. (2012). A literature review and a case study of sustainable supply chains with a focus on metrics. International journal of production economics, 140(1), 69-82. doi:https://doi.org/10.1016/j.ijpe.2012.01.042

Hiermann, G., Puchinger, J., Ropke, S., \& Hartl, R. F. (2016). The electric fleet size and mix vehicle routing problem with time windows and recharging stations. European Journal of Operational Research, 252(3), 995-1018. doi:https://doi.org/10.1016/j.ejor.2016.01.038

Hutchins, M. J., \& Sutherland, J. W. (2008). An exploration of measures of social sustainability and their application to supply chain decisions. Journal of cleaner production, 16(15), 1688-1698. doi:https://doi.org/10.1016/j.jclepro.2008.06.001

Intergovernmental Panel on Climate Change-IPCC. (2015). Climate change 2014: Mitigation of climate change (Vol. 3): Cambridge University Press.

Jaehn, F. (2016). Sustainable operations. European Journal of Operational Research, 253(2), 243-264. doi:https://doi.org/10.1016/j.ejor.2016.02.046

Joshi, Y., \& Rahman, Z. (2015). Factors affecting green purchase behaviour and future research directions. International Strategic management review, 3(1-2), 128-143. doi:https://doi.org/10.1016/j.ism.2015.04.001

Kirschstein, T., \& Meisel, F. (2015). GHG-emission models for assessing the ecofriendliness of road and rail freight transports. Transportation Research Part B: Methodological, 73, 13-33. doi:https://doi.org/10.1016/j.trb.2014.12.004

Koberg, E., \& Longoni, A. (2018). A systematic review of sustainable supply chain management in global supply chains. Journal of cleaner production. doi:https://doi.org/10.1016/j.jclepro.2018.10.033

Kouvelis, P., Chambers, C., \& Wang, H. (2006). Supply chain management research and production and operations management: Review, trends, and opportunities. Production and Operations Management, 15(3), 449-469. doi:https://doi.org/10.1111/j.1937-5956.2006.tb00257.x

Kumar, P., \& Polonsky, M. J. (2017). An analysis of the green consumer domain within sustainability research: 1975 to 2014. Australasian Marketing Journal (AMJ), 25(2), 85-96. doi:https://doi.org/10.1016/j.ausmj.2017.04.009

Lacoste, S. (2016). Sustainable value co-creation in business networks. Industrial Marketing Management, 52, 151-162. doi:https://doi.org/10.1016/j.indmarman.2015.05.018

Leigh, M., \& Li, X. (2015). Industrial ecology, industrial symbiosis and supply chain environmental sustainability: a case study of a large UK distributor. Journal of cleaner production, 106, 632-643. doi:https://doi.org/10.1016/j.jclepro.2014.09.022

Li, B., Chen, W., Xu, C., \& Hou, P. (2018). Impacts of government subsidies for environmental-friendly products in a dual-channel supply chain. Journal of cleaner production, 171, 1558-1576. doi:https://doi.org/10.1016/j.jclepro.2017.10.056

Lin, C., Choy, K. L., Ho, G. T., Chung, S. H., \& Lam, H. (2014). Survey of green vehicle routing problem: past and future trends. Expert systems with applications, 41(4), 1118-1138. doi:https://doi.org/10.1016/j.eswa.2013.07.107

Marques Vieira, L., Dutra De Barcellos, M., Hoppe, A., \& Bitencourt da Silva, S. (2013). An analysis of value in an organic food supply chain. British Food Journal, 115(10), 1454-1472. doi:https://doi.org/10.1108/BFJ-06-2011-0160

Mars, C. (2016). Benefits of Using Cold Water for Everyday Laundry in the U.S.

Mathiyazhagan, K., Govindan, K., NoorulHaq, A., \& Geng, Y. (2013). An ISM approach for the barrier analysis in implementing green supply chain management. Journal of cleaner production, 47, 283-297. doi:https://doi.org/10.1016/j.jclepro.2012.10.042 
Mead, L. (2018). World Business Council for Sustainable Development Report Reviews Companies on Sustainability Reporting.

Melachrinoudis, E. (2011). The location of undesirable facilities. In Foundations of location analysis (pp. 207-239): Springer.

Mena, C., Humphries, A., \& Choi, T. Y. (2013). Toward a theory of multi-tier supply chain management. Journal of Supply Chain Management, 49(2), 58-77. doi:https://doi.org/10.1111/jscm.12003

Mentzer, J. T., DeWitt, W., Keebler, J. S., Min, S., Nix, N. W., Smith, C. D., \& Zacharia, Z. G. (2001). Defining supply chain management. Journal of Business logistics, 22(2), 1 25. doi:https://doi.org/10.1002/j.2158-1592.2001.tb00001.x

Michelsen, O., Fet, A. M., \& Dahlsrud, A. (2006). Eco-efficiency in extended supply chains: A case study of furniture production. Journal of environmental management, 79(3), 290-297. doi:https://doi.org/10.1016/j.jenvman.2005.07.007

Miret, C., Chazara, P., Montastruc, L., Negny, S., \& Domenech, S. (2016). Design of bioethanol green supply chain: Comparison between first and second generation biomass concerning economic, environmental and social criteria. Computers \& Chemical Engineering, 85, 16-35. doi:https://doi.org/10.1016/j.compchemeng.2015.10.008

Mota, B., Gomes, M. I., Carvalho, A., \& Barbosa-Povoa, A. P. (2015). Towards supply chain sustainability: economic, environmental and social design and planning. Journal of cleaner production, 105, 14-27. doi:https://doi.org/10.1016/j.jclepro.2014.07.052

Mota, B., Gomes, M. I., Carvalho, A., \& Barbosa-Povoa, A. P. (2018). Sustainable supply chains: An integrated modeling approach under uncertainty. Omega, 77, 32-57. doi:https://doi.org/10.1016/j.omega.2017.05.006

Munasinghe, M., Jayasinghe, P., Ralapanawe, V., \& Gajanayake, A. (2016). Supply/value chain analysis of carbon and energy footprint of garment manufacturing in Sri Lanka. Sustainable Production and Consumption, 5, 51-64. doi:https://doi.org/10.1016/j.spc.2015.12.001

Nidumolu, R., Prahalad, C. K., \& Rangaswami, M. R. (2009). Why sustainability is now the key driver of innovation. Harvard business review, 87(9), 56-64.

Nielsen, P. (2005). Life cycle assessment supports cold-wash enzymes. SÖFW-journal, 131(10), 24-26.

Nolz, P. C., Absi, N., \& Feillet, D. (2014). A stochastic inventory routing problem for infectious medical waste collection. Networks, 63(1), 82-95. doi:https://doi.org/10.1002/net.21523

NSW Government- The City of Sydney (2018). Cycling Strategy and Action Plan For a more sustainable Sydney 2018-2030. Retrieved from https://www.cityofsydney.nsw.gov.au/ data/assets/pdf file/0011/304796/Cycling St rategy and Action Plan 20182030.pdf

O'Connor, E. L., Sims, L., \& White, K. M. (2017). Ethical food choices: Examining people's Fair Trade purchasing decisions. Food Quality and Preference, 60, 105-112. doi:https://doi.org/10.1016/j.foodqual.2017.04.001

Oliver, R. K., \& Webber, M. D. (1982). Supply-chain management: logistics catches up with strategy. Outlook, 5(1), 42-47.

Osmani, A., \& Zhang, J. (2017). Multi-period stochastic optimization of a sustainable multifeedstock second generation bioethanol supply chain- A logistic case study in Midwestern United States. Land Use Policy, 61, 420-450. doi:https://doi.org/10.1016/j.landusepol.2016.10.028

Pagell, M., \& Shevchenko, A. (2014). Why research in sustainable supply chain management should have no future. Journal of Supply Chain Management, 50(1), 44-55. doi:https://doi.org/10.1111/jscm.12037

Pankaew, P., \& Tobe, M. (2010). Consumer Buying Behavior in a Green Supply Chain Management Context e a Study in the Dutch Electronics Industry. Business Administration. Jönköping University. 
Park, J., Sarkis, J., \& Wu, Z. (2010). Creating integrated business and environmental value within the context of China's circular economy and ecological modernization. Journal of cleaner production, 18(15), 1494-1501. doi:https://doi.org/10.1016/j.jclepro.2010.06.001

Park, K., Kremer, G. E. O., \& Ma, J. (2018). A regional information-based multi-attribute and multi-objective decision-making approach for sustainable supplier selection and order allocation. Journal of cleaner production, 187, 590-604. doi:https://doi.org/10.1016/i.jclepro.2018.03.035

Pishvaee, M. S., Razmi, J., \& Torabi, S. A. (2012). Robust possibilistic programming for socially responsible supply chain network design: A new approach. Fuzzy sets and systems, 206, 1-20. doi:https://doi.org/10.1016/j.fss.2012.04.010

Popovic, T., Barbosa-Póvoa, A., Kraslawski, A., \& Carvalho, A. (2018). Quantitative indicators for social sustainability assessment of supply chains. Journal of cleaner production, 180, 748-768. doi:https://doi.org/10.1016/j.jclepro.2018.01.142

Porter, M. E., \& Kramer, M. R. (2011). The big idea: Creating shared value.

Queensland Government- Department of Transport and Main Roads. (2018). Cycling benefits. Retrieved from https://www.tmr.qld.gov.au/Travel-and transport/Cycling/Benefits.aspx\#rateFeedback

Rao, P., \& Holt, D. (2005). Do green supply chains lead to competitiveness and economic performance? International Journal of Operations \& Production Management, 25(9), 898-916. doi:https://doi.org/10.1108/01443570510613956

Richardson, D. B. (2013). Electric vehicles and the electric grid: A review of modeling approaches, Impacts, and renewable energy integration. Renewable and Sustainable Energy Reviews, 19, 247-254. doi:https://doi.org/10.1016/j.rser.2012.11.042

Rödiger, M., \& Hamm, U. (2015). How are organic food prices affecting consumer behaviour? A review. Food Quality and Preference, 43, 10-20. doi:https://doi.org/10.1016/j.foodqual.2015.02.002

Sahebjamnia, N., Fathollahi-Fard, A. M., \& Hajiaghaei-Keshteli, M. (2018). Sustainable tire closed-loop supply chain network design: Hybrid metaheuristic algorithms for largescale networks. Journal of cleaner production, 196, 273-296.

Santibañez-Aguilar, J. E., González-Campos, J. B., Ponce-Ortega, J. M., Serna-González, M., \& El-Halwagi, M. M. (2014). Optimal planning and site selection for distributed multiproduct biorefineries involving economic, environmental and social objectives. Journal of cleaner production, 65, 270-294. doi:https://doi.org/10.1016/j.jclepro.2013.08.004

Santibañez-Aguilar, J. E., Ponce-Ortega, J. M., González-Campos, J. B., Serna-González, M., \& El-Halwagi, M. M. (2013). Optimal planning for the sustainable utilization of municipal solid waste. Waste management, 33(12), 2607-2622. doi:https://doi.org/10.1016/j.wasman.2013.08.010

Schlegel, T., Puiatti, D., Ritter, H.-J., Lesueur, D., Denayer, C., \& Shtiza, A. (2016). The limits of partial life cycle assessment studies in road construction practices: A case study on the use of hydrated lime in Hot Mix Asphalt. Transportation Research Part D: Transport and Environment, 48, 141-160. doi:https://doi.org/10.1016/j.trd.2016.08.005

Schrettle, S., Hinz, A., Scherrer-Rathje, M., \& Friedli, T. (2014). Turning sustainability into action: Explaining firms' sustainability efforts and their impact on firm performance. International journal of production economics, 147, 73-84. doi:https://doi.org/10.1016/j.ijpe.2013.02.030

Seuring, S., \& Müller, M. (2008). From a literature review to a conceptual framework for sustainable supply chain management. Journal of cleaner production, 16(15), 16991710. doi:https://doi.org/10.1016/j.jclepro.2008.04.020

Shaw, K., Shankar, R., Yadav, S. S., \& Thakur, L. S. (2012). Supplier selection using fuzzy AHP and fuzzy multi-objective linear programming for developing low carbon supply chain. Expert systems with applications, 39(9), 8182-8192.

doi:https://doi.org/10.1016/j.eswa.2012.01.149 
Srivastava, S. K. (2007). Green supply-chain management: a state-of-the-art literature review. International journal of management reviews, 9(1), 53-80. doi:https://doi.org/10.1111/j.1468-2370.2007.00202.x

Srivastava, S. K. (2008). Network design for reverse logistics. Omega, 36(4), 535-548. doi:https://doi.org/10.1016/i.omega.2006.11.012

Stadtler, H. (2008). Supply chain management-an overview. In Supply chain management and advanced planning (pp. 9-36): Springer.

Steg, L., \& Vlek, C. (2009). Encouraging pro-environmental behaviour: An integrative review and research agenda. Journal of environmental psychology, 29(3), 309-317. doi:https://doi.org/10.1016/j.jenvp.2008.10.004

Stindt, D. (2017). A generic planning approach for sustainable supply chain managementHow to integrate concepts and methods to address the issues of sustainability? Journal of cleaner production, 153, 146-163. doi:https://doi.org/10.1016/j.jclepro.2017.03.126

Taghikhah, F., Voinov, A., \& Shukla, N. (2018). Effects of price and availability on consumer behaviour towards Sustainable Food. Paper presented at the Proceeding of 9th International Congress on Environmental Modeling and Software, Fort Collins, Colorado USA.

Tang, C. S., \& Zhou, S. (2012). Research advances in environmentally and socially sustainable operations. European Journal of Operational Research, 223(3), 585-594. doi:https://doi.org/10.1016/j.ejor.2012.07.030

Taufique, K. M. R., \& Vaithianathan, S. (2018). A fresh look at understanding Green consumer behavior among young urban Indian consumers through the lens of Theory of Planned Behavior. Journal of cleaner production, 183, 46-55. doi:https://doi.org/10.1016/j.jclepro.2018.02.097

Thorpe, D., \& Keith, D. (2016). Climate Impacts of Biking vs. Driving. Retrieved from https://keith.seas.harvard.edu/blog/climate-impacts-biking-vs-driving

Tseng, S.-C., \& Hung, S.-W. (2013). A framework identifying the gaps between customers' expectations and their perceptions in green products. Journal of cleaner production, 59, 174-184. doi:https://doi.org/10.1016/j.jclepro.2013.06.050

Tseng, S.-C., \& Hung, S.-W. (2014). A strategic decision-making model considering the social costs of carbon dioxide emissions for sustainable supply chain management. Journal of environmental management, 133, 315-322. doi:https://doi.org/10.1016/j.jenvman.2013.11.023

Vachon, S., \& Klassen, R. D. (2006). Extending green practices across the supply chain: the impact of upstream and downstream integration. International Journal of Operations \& Production Management, 26(7), 795-821. doi:https://doi.org/10.1108/01443570610672248

Varsei, M., \& Polyakovskiy, S. (2017). Sustainable supply chain network design: A case of the wine industry in Australia. Omega, 66, 236-247. doi:https://doi.org/10.1016/j.omega.2015.11.009

Voinov, A. (2017). Participatory Modeling for Sustainability. In Encyclopedia of sustainable technologies (pp. 33-41): Elsevier.

WCED , B. C. (1987). Our common future. In: Oxford University Press Oxford.

White, L., \& Lee, G. J. (2009). Operational research and sustainable development: Tackling the social dimension. European Journal of Operational Research, 193(3), 683-692. doi:https://doi.org/10.1016/j.ejor.2007.06.057

World Bank. (2014). Retrieved from https://data.worldbank.org/

Wu, Z., \& Pagell, M. (2011). Balancing priorities: Decision-making in sustainable supply chain management. Journal of operations management, 29(6), 577-590. doi:https://doi.org/10.1016/j.jom.2010.10.001

Xia, X., Govindan, K., \& Zhu, Q. (2015). Analyzing internal barriers for automotive parts remanufacturers in China using grey-DEMATEL approach. Journal of cleaner production, 87, 811-825. doi:https://doi.org/10.1016/j.jclepro.2014.09.044 
Xiong, Y., Zhou, Y., Li, G., Chan, H.-K., \& Xiong, Z. (2013). Don't forget your supplier when remanufacturing. European Journal of Operational Research, 230(1), 15-25. doi:https://doi.org/10.1016/j.ejor.2013.03.034

You, F., Tao, L., Graziano, D. J., \& Snyder, S. W. (2012). Optimal design of sustainable cellulosic biofuel supply chains: multiobjective optimization coupled with life cycle assessment and input-output analysis. AIChE Journal, 58(4), 1157-1180. doi:https://doi.org/10.1002/aic.12637

Zand, F., Yaghoubi, S., \& Sadjadi, S. J. (2019). Impacts of government direct limitation on pricing, greening activities and recycling management in an online to offline closed loop supply chain. Journal of cleaner production, 215, 1327-1340. doi:https://doi.org/10.1016/j.jclepro.2019.01.067

Zhalechian, M., Tavakkoli-Moghaddam, R., Zahiri, B., \& Mohammadi, M. (2016). Sustainable design of a closed-loop location-routing-inventory supply chain network under mixed uncertainty. Transportation Research Part E: Logistics and Transportation Review, 89, 182-214. doi:https://doi.org/10.1016/i.tre.2016.02.011

Zhang, M., Wiegmans, B., \& Tavasszy, L. (2013). Optimization of multimodal networks including environmental costs: a model and findings for transport policy. Computers in industry, 64(2), 136-145. doi:https://doi.org/10.1016/j.compind.2012.11.008

Zhu, Q., \& Sarkis, J. (2004). Relationships between operational practices and performance among early adopters of green supply chain management practices in Chinese manufacturing enterprises. Journal of operations management, 22(3), 265-289. doi:https://doi.org/10.1016/j.jom.2004.01.005 